\title{
The genus Arrhopalites (Collembola: Sminthuridae) in the United States and Canada ${ }^{1}$ )
}

\author{
By Kenneth Christiansen²)
}

With plates 11 (1) - 19 (9)

This genus is one of the most widespread cave forms throughout the Holarctic region. Most of the forms found in caves are troglophiles, and thus any major consideration must involve all the species of the group.

Recent work on the members of this genus has completely altered the basis of its taxonomy. Stach in 1945 analyzed the rather intricate external anatomy and in 1947 Denis added a system for naming the setae of the dens. Other major additions to the system were made by Cassagnau and Delamare in 1953, by Stach in 1956, and finally by Gisin in his monumental work of 1960 . Numerous smaller publications of great importance came out during this period. Yosii, for example, in 1954 and 1956 analyzed the Japanese species of the group and added some basic information. This present study is the first attempt to apply the system to the Nearctic forms and to add a little to our general knowledge of the group.

In the course of the past twenty years the huge majority of specimens of this genus found in North America have been called A. binoculatus. As Stach has pointed out, this name must give way to several others, and the one most typical for epigeic specimens is the European $A$. principalis. This species, however, does not occur in North America and a number of indigenous species have been described: Packard's A. ferruginaeus in 1888, Folsom's A. benitus in 1896, Banks' A. mammouthia in 1897, Mills' A. diversus in 1934, and Jacot's A. whitesidei in 1938. These names have generally been ignored or mistreated due to the fact that only the rare diversus had an adequate description. In

\footnotetext{
1) This work was made possible by N.S.F. grant 15956.

2) Grinnell College, Grinnell, Iowa (U.S.A.).
} 
the course of this study I have had an opportunity to examine the types of all of the species named and have been able to place the various forms with some degree of certainty.

Arrhopalites has a number of characteristics available for taxonomic purposes, and several of these are both clear cut and relatively constant. The biggest difficulty is that some characteristics are usable only in adult female individuals, and in most cases the males can be placed only tentatively, or when they are associated with females of an identifiable species. A second big problem arises from the rarity of most of the species. This is true in both epigeic and cave habitats, but it is most striking in the former. A particular species may be very abundant in caves, but even here the specimens of Arrhopalites may be few and far between when other cave genera such as Oncopodura, Sinella or Onychiurus are abundant. The result of this is that anything approximating a complete work would require exhaustive collection of a whole region, as shown by: (1) the continuous discovery of new species of the genus throughout Europe, and (2) the rarity of multiple collections. This also means that many of the samples examined were extremely meager, and hence the present work must be viewed as preliminary. This is so serious in this group that three of the species here examined were represented by one poor specimen each. These forms are briefly described and/or keyed and charted, but they are not named. I felt naming unwise until better material was available for examination.

This study was made possible by the assistance of a large number of people, and I wish to thank all of them. The study was greatly facilitated by the extensive preliminary work and collection of Dr. H. B. Mills. A good deal of the remaining epigeic material came through the courtesy of Mrs. Mary Quigley of the U.S. National Museum, while much of the cave material was collected by Dr. T.C. Barr of the University of Kentucky. Most of the labor of measuring, mounting, etc., was done by my two assistants, Peter Snyder and Jack Spence. A comparison between the Nearctic species and a large number of old world forms was made possible by the loan of large series of specimens from Dr. Delamare Deboutteville. It is clear both from the present work and from the descriptions available that many, if not most, of the types of organ variation seen in European species are also seen in the Nearctic material. However, the combinations of characteristics are almost always different. Thus, A. altus has ungues and antennae very much like $A$. aggtelekensis, but dental spination like $A$. pygmaeus and a subanal appendage resembling $A$. furcatus. Only two species resemble European forms enough to be considered synonyms. These 
are A. pygmaeus and A. caecus. In both cases it is possible that we are dealing with widespread species such as Entomobrya nivalis.

The new characteristics introduced by Stach, and worked out by other authors, are difficult to use, and I will briefly describe and discuss the various characteristics and point out a few new modifications. The anal valves of the females are equipped with a variety of setae and subanal appendages. These are extremely complex (see Plate 12) and will be discussed later. The largest setae vary considerably in size and structure (see Fig. 85-91) and may bear flanges with deep or shallow serrations at their bases. The presence of supplementary short spines on the anal valves is characteristic of species of the $A$. caecus group.

There is a characteristic chaetotaxy on the dorsal (Fig. 3) and ventral (Fig. 4) surfaces of the dens. These setae vary somewhat in position, and those described as being in a particular row may not always follow each other in a straight line; however, it is usually easy to determine to which series a particular setae belongs. As can be seen from Plate 4, there are at least two basic types of structure of these organs in Nearctic material, each having several modifications. One of these modifications occurs in the distribution of the spine-like setae and the degree to which they are spine-like. Figure 5 shows a series of $\mathrm{L}_{2}$ spines, and it can be seen from this that the question of spine-like or not may be a difficult one. In most cases the setae are either like D and clearly spine-like, or like A and clearly not. (In notation of dental chaetotaxy, spine-like setae are indicated with capital letters while others are shown with small letters.)

The cephalic chaetotaxy is quite regular in the disposition of setae (see Fig. 2). The lettering used here is new and should be some aid in indicating the type of chaetotaxy and the distribution of heavy spines on the head. The only significant variation in the disposition of the setae is the presence of $\mathrm{M}_{1}$. It is absent in most species and present in only some of the members of any one species so far examined.

The mucro is another characteristic which requires some explanation. It is usually trough shaped with both edges serrate. The ventral margin may be straight or variously indented (Fig. 6), while the apex of the organ may be pointed, flanged or bulbed. The unguis is fairly constant throughout the group although minor differences may occur (see Plate 13), and these are sometimes useful in separation.

Over two hundred specimens belonging to eight species were measured in this study. The sum of the data is too bulky for reprinting here, but is available to interested persons upon request. As with the 
Entomobryini previously worked on, most of the organ ratios of the Arrhopalites can be expressed as straight lines (see Graph 17), with the exception of $A$. clarus and $A$. altus which usually have somewhat differing ratios.

A number of characteristics did not fit the pattern above. Most interesting was the evolutionary progression found in the first subsegment of the fourth antennal segment (see Graph 18 above). Here we have a situation similar in some respects to that seen in Sinella and Pseudosinella. The trend, however, is not carried out if one considers the antenna as a whole, but this is probably a result of the complex nature of the antennae in these animals and the adjustments made in subsegmentation. A different variation from the normal occurs if we consider the relationship between the tibiotarsus and the cephalic diagonal (see Graph 18 below). Here it is clear that a curve rather than a straight line graph is required to fit the data, and A. clarus fits on this curve very well.

In view of all these facts it is clear that most of the differences in ratios found in the genus are merely a result of the different sizes of the animals being examined and the fact that they all represent parts of the same curve. These ratios are not entirely invalid distinctions since there are significant size differences among the species, but it is important to realize that apparent ratio differences are merely differences in size. The animals seem to fall into four basic size categories, as can be seen from Graph 18 below. If we consider the hind tibiotarsus as a suitable size measurement, then we have $A$. caecus and $A$. benitus averaging about $0.13 \mathrm{~mm}$., A. hirtus and A. dubius about $0.18 \mathrm{~mm} .$, A. pygmaeus and A. whitesidei about $0.25 \mathrm{~mm}$., and A. clarus and A. altus (?) about $0.45 \mathrm{~mm}$. It should be noted that a great deal of overlap occurs, and only in the extremes are the sizes entirely separate.

A considerable number of the important characteristics of this genus can be roughly described in a formula or a number. One striking exception to this is the subanal appendage of the female. Here the complexity of the organ and the extensive variation found within a single species makes description lengthy and confusing. It is possible, however, to derive a simple expression of both the individual shape and the variation of the organ if we consider the morphological relationships among the various types of structure. In Figure 11 I have attempted to achieve a matrix of this sort. The simplest form to which all the other types can be related is the form placed at the center of the diagram. Around the periphery are located the extremes in differentiation of the particular organ found in the various holarctic species. 
Other forms are envisioned as intermediates which can be normally placed along radii running from the center outward, or occasionally as intermediates running between such radii. To clarify the types of structure expected along the various radii those considered to be at the halfway mark are illustrated in each case. Each radius is numbered, and the stage of development along each radius is represented by a series of concentric circles. Although the radii furnished are enough to take care of the presently known holarctic species, blank radii are left for future additions.

Now almost any organ form can be simply described by a combination of its radius number and lettered circle. Thus the organ shown in Figure 7 would be described as $13 \mathrm{E}$, that shown in Figure 19 as 6D while that shown in Figure 23 would be $14 \mathrm{D}$. Occasionally a specimen will appear as an intermediate between radii. In this case the organ should be described as follows: $4 B 5$, indicating circle $\mathrm{B}$ and intermediate between radii $4 \& 5$. Thus the organ shown in Figure 17 would be $5 C 6$.

This system allows not only a moderately exact description of a single organ but also furnishes a very quick method for describing the variation found within a single species. In most cases this will follow a single radius and should be designated as follows: A. caecus $14 \mathrm{~A}-\mathrm{E}$. In some cases, the variation encompasses parts of two radii with gradation between these. In this case they should be shown as follows: A. pygmaeus: $10 \mathrm{~A}-\mathrm{C}, 11 \mathrm{D}-\mathrm{A}$. The gradation between radii is shown by the superscribed above the appropriate places, and its absence would indicate discrete variations.

This system and matrix is set up on a purely morphological basis and should not in any way be assumed to represent the evolutionary patterns involved. This may occur but it is not the goal, nor did it enter into the formulation.

In the table which follows, the various organs which can be readily represented are shown for all the Nearctic species of the group. It should be noted that while the matrix is designed for all Holarctic species, the table deals only with the Nearctic forms and, hence, not all the radii are used.

In closing this section, I wish to point out that in several cases I have stretched a species diagnosis to include what are probably two or more species, merely because of the poor nature of the presently available samples. When this is added to the three unnamed forms listed here, and the probability that no more than two-thirds of the actual Nearctic species have been collected, it is clear that this is a 
preliminary work and that much remains to be done. I hope that this paper will do something toward laying a foundation for this work.

All type material mentioned herein will be deposited in the Museum of Comparative Zoology at Harvard University, Cambridge, Massachusetts, unless otherwise noted.

\section{Tribe Arrhopalini}

\section{Genus ARRHOPALITES Borner}

Synonymy:

Arrhopalites Borner, 1906, Mitt. Naturhist. Mus. Hamburg 23: 182. Type by original designation Sminthurus Caecus Tullberg, 1871, Ofv. Kongl. Vet.-Akad. 28: 146.

Coecarrhopalites Yosii, 1954, Kontyu, 20: 20-21. No type species designated. Synonymized with Arrhopalites Gisin, 1960, Collembolenfauna Europas: 270.

Pseudarrhopalites Stach, 1945, The Apterygotan Fauna of Poland in relation to the world fauna, Family Sminthuridae, Acta Monogr. Mus. Nat. Krakow: 62. Type by original designation A. diversus Mills, 1934, A Monograph of the Collembola of Iowa.

Sminthurinae having three or fewer eyes per side, females equipped with subanal appendages, dentes normally carrying spines on dorsal surface, fourth antennal segment normally subdivided into five or more subsegments, pigment usually reduced.

This easily recognized genus has had a number of genera created for different sections; however, in view of the small number of species concerned, and the large number of common characteristics, I do not feel that there is any merit in fragmentation of a clearly limited and related unit.

\section{Genus COLLO PHORA Delamare\& Massoud}

Synonymy:

Collophora Delamare-Deboutteville \& Massoud, 1964, Zool. Anz. 172: 29-36. Type by original designation Arrhopalites quadrioculatus Denis, 1933, Boll. Lab. Zool. Portici 25: 284-285.

Following the lead of Richards (unpublished) these authors have erected a new genus to include Denis's species and one new form. The genus is readily separated from Arrhopalites on a basis of the capitate abdominal bothriotrichia, the fused fourth and fifth abdominal segments and several chaetotactic features. 


\section{KEY TO THE NEARCTIC MEMBERS \\ OF THE TRIBE ARRHOPALINI}

1. Four eyes per side ............ Collophora quadrioculatus (Denis) Two or less eyes per side ................ (Arrhopalites) -2

2. Anal valves with small spines in addition to normal setae (Fig. 1) 3 Anal valves without small spines $\ldots \ldots \ldots \ldots \ldots \ldots \ldots \ldots \ldots$ 4

3. Unguis with long filament projecting from inner lamella (Fig. 2) .... $\ldots \ldots \ldots \ldots \ldots \ldots \ldots \ldots \ldots \ldots \ldots \ldots$. diversus Mills (epigeic) Unguis without long filament from inner lamella ...............

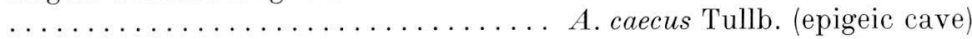

4. Seven or more subsegments of fourth antennal segment ...... 5 Six or less subsegments of fourth antennal segment .......... 10

5. Fourth antennal subsegments eight or more .............. 6 Fourth antennal subsegments seven ................ 7

6. Female subanal appendage slender (Fig. 1), acuminate, apically bifurcate

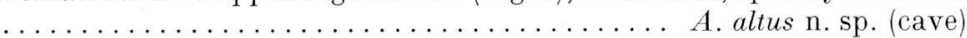
Female subanal appendage rod-like, apically weakly serrate ........ $\ldots \ldots \ldots \ldots \ldots \ldots \ldots \ldots \ldots \ldots \ldots \ldots \ldots \ldots \ldots \ldots \ldots$. sp. (epigeic, Oregon)

7. Female subanal appendage deeply serrate $\ldots \ldots \ldots \ldots \ldots \ldots . \ldots$ Female subanal appendage weakly serrate or smooth ........ 9

8. Dorsum of dens with seta $\mathrm{e}_{6}$ absent or present, pigment weak, eyes $1 /$ side A. hirtus n. sp. (doubtful epigeic + cave) Dorsum of dens with seta $e_{6}$ present, pigment heavy, eyes usually $2 /$ side $\ldots \ldots \ldots \ldots \ldots \ldots \ldots \ldots \ldots \ldots \ldots \ldots \ldots \ldots \ldots \ldots \ldots$ A. bellingeri n. sp. (epigeic)

9. Cephalic spines weak .................... clarus n. sp. (cave) Cephalic spines heavy ..................... (cave, Pennsylvania)

10. Dorsum of dens with seta $\mathrm{Id}_{3}$ absent $\ldots \ldots \ldots \ldots \ldots \ldots \ldots \ldots$ Dorsum of dens with seta $\operatorname{Id}_{3}$ present $\ldots \ldots \ldots \ldots \ldots \ldots \ldots \ldots \ldots \ldots \ldots$

11. Subanal appendage of female strongly curved, acuminate, weakly or sparsely serrate in pinnate fashion. A. whitesidei Jacot (epigeic + cave) Subanal appendage of female rod-like, deeply serrate over apical onethird in palmate fashion ........ A. benitus Folsom (epigeic + cave)

12. Dorsum of dens with seta $L_{3}$ present $\ldots \ldots \ldots \ldots \ldots \ldots \ldots \ldots$ Dorsum of dens with seta $\mathrm{L}_{3}$ missing $\ldots \ldots \ldots \ldots \ldots \ldots \ldots \ldots \ldots$

13. Dorsum of dens with seta $\mathrm{e}_{6}$ absent $\ldots \ldots \ldots \ldots$. hirtus (see above) Dorsum of dens with seta $e_{6}$ present $\ldots \ldots \ldots \ldots \ldots \ldots \ldots \ldots$

14. Subanal appendage of female acuminate curved. A. sp. epigeic Calif. Subanal appendage of female rod-like ....... A. dubius n. sp. (cave)

15. Subanal appendage of female rod-like, apically ciliate or flanged . . 16 Subanal appendage of female deeply serrate in palmate fashion or acuminate and curved ......................... 17

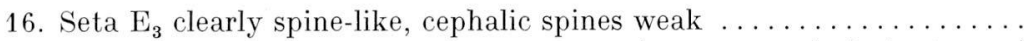

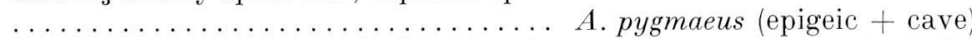
Seta $e_{3}$ not spine-like, cephalic spines heavy. A. amarus n. sp. (epigeic)

17. Subanal appendage of female acuminate curved, feathered or smooth

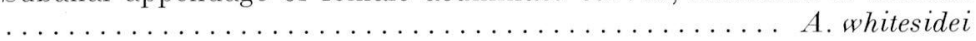
Subanal appendage of female deeply serrate in palmate fashion A. bimus n.sp. 
Table Comparative Table Nearctic Species Arrhopalites sens. lat.

\begin{tabular}{|c|c|c|c|c|c|}
\hline Name & \begin{tabular}{|c|} 
No. 4th \\
Antennal \\
Sub- \\
segments \\
\end{tabular} & $\begin{array}{c}\text { Cephalic } \\
\text { Spines }\end{array}$ & $\begin{array}{l}\text { Subanal } \\
\text { Append. }\end{array}$ & $\begin{array}{c}\text { Dorsal } \\
\text { Dental } \\
\text { Chaetotaxy }\end{array}$ & $\begin{array}{l}\text { Eye } \\
\text { Number } / \\
\text { Side }\end{array}$ \\
\hline A. caecus & $\begin{array}{c}5 \\
\text { often } \\
\text { unclear }\end{array}$ & strong & $14 \mathrm{~A}-\mathrm{E}$ & $\begin{array}{l}\mathrm{E}_{1} \mathrm{e}_{2} \mathrm{e}_{3} \mathrm{e}_{4} \mathrm{e}_{5} \mathrm{e}_{6} \\
\mathrm{~d}_{1} \mathrm{~d}_{2} \mathrm{~d}_{3} \mathrm{~d}_{4} \mathrm{~d}_{5} \mathrm{~d}_{6} \\
\mathrm{~L}_{1} \mathrm{l}_{2} \mathrm{l}_{3}\end{array}$ & 1 \\
\hline A. pygmaeus & 5 & weak & $\begin{array}{l}\text { I D-A } \\
10-\mathrm{C}\end{array}$ & $\begin{array}{l}\mathrm{E}_{1} \mathrm{e}_{2} \mathrm{E}_{3} \mathrm{e}_{4} \mathrm{e}_{5} \\
\mathrm{e}_{6} \mathrm{e}_{7} \\
\mathrm{~d}_{1} \mathrm{~d}_{2} \\
\mathrm{Id}_{1} \mathrm{Id}_{2} \mathrm{Id}_{3} \mathrm{Id}_{4} \\
\mathrm{~L}_{1} \mathrm{~L}_{2} \mathrm{~L}_{3}\end{array}$ & 1 \\
\hline A. bimus & 5 & weak & 1D-C15C & as above & 1 \\
\hline A. whitesidei & 5 & strong & $6 \mathrm{C} 7 \mathrm{C}-\mathrm{E}$ & $\begin{array}{c}\text { as above } \\
\mathrm{Id}_{3} \text { sometimes } \\
\text { missing }\end{array}$ & 1 \\
\hline A. benitus & 5 & $\begin{array}{l}\text { strong } \\
\text { to weak }\end{array}$ & $5 \mathrm{C}-\mathrm{E}$ & as above & 1 \\
\hline A. bellingeri & 7 & strong & $5 \mathrm{C}-\mathrm{D}$ & as pygmaeus & 2 \\
\hline A. hirtus & $6-7$ & weak & $5 \mathrm{C} 6 \mathrm{C}-\mathrm{E}$ & $\begin{array}{c}\text { as pygmaeus } \\
\text { except } \mathrm{e}_{6} \\
\text { missing }\end{array}$ & 1 \\
\hline A. dubius & 5 & $\begin{array}{c}\text { weak or } \\
\text { absent }\end{array}$ & $14 \mathrm{~A}$ & $\begin{array}{c}\text { as pygmaeus } \\
\text { except } \mathrm{L}_{3} \\
\text { missing }\end{array}$ & 1 \\
\hline A. clarus & 7 & weak & $10 \mathrm{C}-\mathrm{D}$ & $\begin{array}{l}\mathrm{E}_{1} \mathrm{e}_{2} \mathrm{e}_{3} \mathrm{e}_{4} \mathrm{e}_{5} \\
\mathrm{e}_{6} \mathrm{e}_{7} \\
\mathrm{~d}_{2} \mathrm{~d}_{3} \\
\mathrm{~d}_{1} \mathrm{Id}_{2} \mathrm{Id}_{3} \mathrm{Id}_{4} \\
\mathrm{~L}_{1} \mathrm{~L}_{2} \mathrm{~L}_{3}\end{array}$ & 1 \\
\hline A. amarus & 6 & strong & $14 \mathrm{D}-\mathrm{E}$ & $\begin{array}{l}\mathrm{E}_{1} \mathrm{e}_{2} \mathrm{e}_{3} \mathrm{e}_{4} \mathrm{e}_{5} \\
\mathrm{e}_{6} \mathrm{e}_{7} \\
\mathrm{~d}_{1} \mathrm{~d}_{2} \\
\mathrm{Id}_{1} \mathrm{Id}_{2} \mathrm{Id}_{3} \mathrm{Id}_{4} \\
\mathrm{~L}_{1} \mathrm{~L}_{2} \mathrm{~L}_{3}\end{array}$ & 1 \\
\hline C.quadrioculatus & 5 & weak & $\begin{array}{l}13 \mathrm{D}-\mathrm{A} \\
15 \mathrm{~A}-\mathrm{B}\end{array}$ & $\begin{array}{l}\mathrm{E}_{1} \mathrm{e}_{2} \mathrm{e}_{3} \mathrm{e}_{4} \\
\mathrm{~d}_{2} \\
\mathrm{Id}_{1} \mathrm{Id}_{2} \mathrm{Id}_{3}\end{array}$ & 4 \\
\hline A. altus & $9-10$ & weak & $10 \mathrm{E}$ & as pygmaeus & 1 \\
\hline A. diversus & none & weak & $13 \mathrm{E}$ & $\begin{array}{l}\mathrm{E}_{1} \mathrm{E}_{2} \mathrm{E}_{3} \mathrm{E}_{4} \mathrm{E}_{5} \\
\left(\mathrm{e}_{6}\right) \mathrm{e}_{7} \\
\mathrm{~d}_{1} \mathrm{~d}_{2} \mathrm{~d}_{3} \mathrm{~d}_{4} \mathrm{~d}_{5} \mathrm{~d}_{6} \\
\mathrm{~L}_{1} \mathrm{~L}_{2} \mathrm{~L}_{3}\left(\mathrm{~L}_{4}\right)\end{array}$ & 1 \\
\hline A. sp. (Oregon) & 7 & strong & $1 \mathrm{E}$ & ? & 1 \\
\hline A. sp. (Penn.) & 8-9 & absent & $6 E 7$ & $?$ & 1 \\
\hline A. sp. (Calif.) & none (?) & weak & $7 \mathrm{E}$ & $\begin{array}{l}\mathrm{E}_{1} \mathrm{e}_{2} \mathrm{e}_{3} \mathrm{e}_{4} \mathrm{e}_{5} \\
\mathrm{~d}_{1} \mathrm{~d}_{2} \\
\mathrm{Id}_{1} \mathrm{Id}_{2} \mathrm{Id}_{3} \\
\mathrm{~L}_{1} \mathrm{l}_{2}\end{array}$ & $2(?)$ \\
\hline
\end{tabular}


ARRHO PALITES ALTUS new species

Figures: 13, 39, 60, 69, 83, 100

Antennae long, fourth antennal segment divided into nine subsegments. Third segment without sign of swelling. Longest setae of fourth antennal segment about three times as long as diameter of segment, those of third segment about twice as long as segmental diameter. Chaetotaxy of dorsum of head normal, M1 absent. None of the setae strikingly spine-like, but those of IL and L series and A3 somewhat thicker than the others. Eyes clear, one per side. No spinelike setae on thorax or abdomen. The largest setae of the anal valves subequal to the subanal appendages in size, and not flanged. Ungues and empodial appendages of fore- and hind-legs similar in shape. The posterior and middle pairs are somewhat shorter than the fore ungues and have a clear inner tooth, absent in the fore ungues. Empodial appendages with clear apical filaments and marked corner tooth. Mucro with marked apical flange and smooth ventral margin. Chaetotaxy of dens as in A. pygmaeus. $\mathrm{Ve}_{4}$ a little more than one fourth of way from base to apex of dens. Tenaculum with posterior unpaired lobe definitely longer than anterior lobe. Female subanal appendage acuminate, straight with bifurcate tip. Male unknown.

Discussion:

This well marked species resembles $A$. clarus in some respects, but is easily differentiated by the fact that the spines of the dens are clear and relatively heavy, in contrast to the seta-like structure seen in that species. Only two specimens of this species were seen and both came from a single cave. It is very likely that this is a troglobite species of very local distribution. Type - Holotype female.

Distribution:

Known only from type locality: Eyeless Fish Trail, Floyd Collins Crystal Cave, Edmonson County, Kentucky, September 23, 1956, Barr coll.

ARRHO PALITES BELLINGERI new species

Figures: 35, 42, 51, 75, 98, 99

Color dark reddish brown over whole of dorsum, head, and appendages: pale only on intersegmental membranes of thorax and ventral surfaces. Pigment not uniform but with numerous small circular pale spots throughout. Antennae usually stout with segments, fusiform in shape. Fourth antennal segment with seven subsegments, but these are often difficult to distinguish in mounted specimens. Two eyes per 
side in the form of a large double pigment spot with one clear and one weakly developed cornea. Longest setae of third and fourth antennal segments slightly longer than diameter of segment at that level. Chaetotaxy of head normal with $\mathrm{M}_{1}$ absent; setae of $1 \mathrm{~L}$ and $\mathrm{L}$ series spine-like, others normal. First row of thoracic setae weakly spinelike. Largest setae of anal valves somewhat thicker than subanal appendages, without flange at base. Fore and hind ungues, with clear median inner tooth and tunica. Empodial appendages differentiated, posterior pair lanceolate while those of the fore appendages are basally expanded and internally excavate. All with long apical filaments and weak corner teeth. Mucro pointed and with a very weak indentation on ventral surface. Dental chaetotaxy as in A. pygmaeus. $\mathrm{Ve}_{4}$ about one-fourth of distance from base to apex of dens. Tenaculum normal. Subanal appendage of female as in A. benitus.

\section{Discussion:}

The most striking feature of this species is the possession of more than one pair of eyes; however, this characteristic is not a clear one. In most of the specimens it is possible to see two pigment cups in close contact, but it is possible to see two separate cornea in only a few specimens and even here the second cornea is very small. In a few cases the whole structure looks like a single eye with a very large pigment spot, but in the majority of cases the initial appearance is of two contiguous eyespots equipped with a single very large cornea. The species resembles $A$. benitus in many respects, but can be readily distinguished on a basis of the subsegments of the fourth antennal segment and the dental chaetotaxy. It resembles the European $A$. principalis more than any other species seen, but can be readily distinguished from this species on the basis of the subsegments of the fourth antennal segment, the eye strueture and details of the cephalic chaetotaxy. It has the heaviest pigmentation of any species examined in this study, and some of the specimens appear a dark reddish brown to the naked eye even when preserved in alcohol. It is likely that they are even darker in life. Types - Holotype female, nine paratypes.

Distribution:

Known only from type locality: Schofield Pass, Colorado, 10,000 ft. elev. August 8, 1961, Peter Bellinger coll. 
ARRHOPALITES BENITUS Folsom

Figures: 5B, 5C, 36-38, 44, 55, 62, 63, 64, 71, 74

Smynthrus benitus Folsom, 1896, Psyche 7: 446-450 [Type: Arlington, Mass.; Mus. Comp. Zool., Harvard].

Arrhopalites benitus Mills 1934, 93, A Monograph of the Collembola of Iowa. Arrhopalites binoculatus sensu Mills 1934, Maynard 1951, and other American authors.

Arrhopalites sub-binoculatus Denis, 1933, Boll. Lab. Zool. Portici 25: 287-288

[Type: Apaican, Costa Rica].

Antennae normal with five subsegments on fourth antennal segment. Longest setae of third and fourth antennal segmentabout twice the diameter of these segments. Eyes clear, one per side. Chaetotaxy of head normal with setae of IL and L series heavy and spine-like. Anterior most row of thoracic setae of weakly spine-like. Fore ungues slightly more slender than hind. All ungues with clear inner median tooth and all empodial appendages equipped with a clear corner tooth. Empodial appendages with strong apical filaments as long as, or longer than, the appendages. Mucro with ventral margin straight and a clear apical knob or flange. Dental chaetotaxy normal, except for the absence of seta $\mathrm{Il}_{3}$. Ventral setae with $\mathrm{Ve}_{4}$ more than one third of distance from base to apex of dens. Tenaculum as in A. pygmaeus, except for posterior unpaired lobe, which is somewhat shorter than the anterior two. Female subanal appendage palmate and deeply serrate over apical one third.

\section{Discussion:}

This is the only species of epigeic Arrhopalites which can be said to be anything near common. About $80 \%$ of the epigeic collections examined have turned out to be of this species. The species is also the most variable of all the species examined. However, all attempts to split it into a number of different species fail on the points of the graded nature of variation, and the failure of any two characteristics to vary concomitantly. The most striking variation concerns the cephalic chaetotaxy. The spine-like setae of the head vary both in shape and in number. In all cases they are clearly distinguishable from the normal setae, but they may be anything from narrow cones to massive, basally swollen forms (see Fig. 74). The most common form has the spine-like setae limited to $A_{3}, \mathrm{IL}_{1}, \mathrm{IL}_{2}, \mathrm{~L}_{1}$, and this is the situation seen in the type specimens. $\mathrm{L}_{2}$ may also be spine-like in these forms but it is usually hidden beneath the head. The various types of spine distribution are summarized in the table. 
In addition to this variation, seta $\mathrm{M}_{2}$ is frequently absent and $\mathrm{M}_{1}$ is frequently present. The distribution of these various cephalic chaetotaxy types does not seem to follow any particular geographic pattern, although the samples examined were not inclusive enough to state this with authority.

Table

\begin{tabular}{|c|c|c|c|c|c|c|c|c|}
\hline \multicolumn{2}{|c|}{ Cephalic spines $=x$} & \multicolumn{6}{|c|}{ Cephalic setae (not spine-like) $=+$} & \multirow[b]{2}{*}{$\mathrm{L}_{1}$} \\
\hline Occurrence & $\mathrm{M}_{5}$ & $\mathrm{M}_{4}$ & $\mathrm{M}_{1}$ & $\mathrm{~A}_{3}$ & $A_{1}$ & $\mathrm{IL}_{1}$ & $\mathrm{I} \mathrm{L}_{2}$ & \\
\hline $\begin{array}{l}\text { Common } \\
\text { (A. benitus types) }\end{array}$ & + & + & + & $x$ & + & $x$ & $x$ & $x$ \\
\hline Uncommon & $x$ & $x$ & + & $x$ & + & $x$ & $x$ & $\times$ \\
\hline Rare & + & + & + & + & + & $x$ & $x$ & $x$ \\
\hline Rare & + & $x$ & + & + & + & $x$ & $x$ & $x$ \\
\hline Common & $x$ & + & + & $x$ & $x$ & $x$ & $x$ & $x$ \\
\hline \multicolumn{9}{|l|}{$\begin{array}{l}\text { (A. sub-binoculatus } \\
\text { types) }\end{array}$} \\
\hline Common & $x$ & $x$ & $x$ & $x$ & + & $x$ & $x$ & $x$ \\
\hline Rare & $x$ & + & $x$ & $x$ & + & $x$ & $x$ & $x$ \\
\hline
\end{tabular}

There is also a great deal of variation in the structure of the dental spines. In some cases the spines of the L series are relatively short and end abruptly, but in most cases the spines of this series have a short filamentous prolongation. The claws normally have a clear tunica. However, in some specimens or whole populations the tunica may be absent, or at least not readily visible. The mucro normally has a clear apical knob or flange, but in a few specimens it appears to be pointed. The large setae on the anal valves are normally not flanged at the base. However, a few specimens show a slight expansion on the basal portion without any clear serrations.

I have examined the types of both A. sub-binoculatus Denis and A. benitus Folsom. They are similar in every respect save one: the cephalic chaetotaxy. In this respect the two forms appear to be different parts of what is a large pattern of variation (see chart above); however, the nature of this variation does not merit separation of the two forms as different species. Further analysis of the geographical variation and genetics of the forms will be required before the real basis of this variation can be established.

This form is similar in many respects to the European A.principalis; however, it can readily be separated on a basis of the dental chaetotaxy, viz., $\mathrm{IL}_{3}$ absent in benitus, present in $A$. principalis. This characteristic is perfectly constant in the Nearctic and Neotropical 
forms and appears to be constant in the European forms. In addition to this, the fourth antennal segment has only five subsegments in $A$. benitus, with only an occasional specimen showing an indication of the sixth segment, whereas $A$. principalis normally has six subsegments.

Single specimens identifiable as $A$. benitus were seen from two caves, one in Virginia and one in West Virginia. The former was fairly typical of the species, but the latter displayed many unusual characteristics. The first subsegment of the fourth antennal segment was considerably longer than normal, and the hind ungues were more slender than in any of the comparable epigeic forms. It appears likely that this represents a considerably isolated population. However, the individual concerned was much larger than normal for this species, and it is necessary to have a better sample before it can be determined that this form does or does not deserve specific recognition. It agrees well with the species on most of the characteristics of importance (i.e. cephalic chaetotaxy, dental chaetotaxy, and subanal appendages).

Distribution:

Type locality: Arlington, Mass., June 1896. Otherwise generally distributed over North and Central America. I have examined specimens from twelve states, three Canadian Provinces, and three Central American and Northern South American countries. Other records include almost every major region of the continent. Only two records from caves, each of a single specimen: McClung Cave, Greenbrier Co., West Virginia, Aug. 10, 1958, Barr coll.; Breathing Cave, Bath Co., Virginia, August 28, 1958, Barr coll.

ARRHOPALITES BIMUS new species

Figures: 31, 41, 61, 68, 82, 94

Antennae with five subsegments on fourth antennal segment. Longest setae on third and fourth segments about twice as long as diameter of segments. Cephalic chaetotaxy normal with M1 absent. Setae all slender, none strikingly spine-like, those of IL series straighter than others. Eyes prominent, conical. No striking spine-like setae on thorax. Anal valves with largest setae not strikingly different from others, considerably more slender than subanal appendages. Hind ungues only slightly thicker than fore ungues, all with clear median inner tooth and tunica. Empodial appendages all look somewhat like normal fore appendages and with prominent corner tooth. Dental chaetotaxy as in pygmaeus. $\mathrm{Ve}_{4}$ about one third of way from base to apex of dens. Mucro with clear flange at apex. Tenaculum normal. Female subanal 
appendage rod-like to curved with heavy moderate serration on dorsal surface of apical one fourth of length. Male unknown.

Discussion:

This species resembles $A$. pygmaeus in many respects, most notably in its dental and cephalic chaetotaxy. It is easily separated on two bases, first the structure of the female subanal appendages, which resemble $A$. benitus more than they do pygmaeus, and second, the small size of the large setae of the anal valves.

In most respects this species resembles $A$. hirtus, and in fact it may be part of the geographical variation of this species; however, the two are presently easily separated by the fore ungues, toothed in hirtus, untoothed in A. bimus; the fourth antennal segment, six to seven subsegments in hirtus, five segmented in bimus; and the empodia appendages, normal in hirtus and similar to each other in bimus. In this last characteristic the condition seen in bimus is rarely found in the genus. On the whole it appears to be a well marked species, and quite probably additional collections will show it to be widespread in the northern tier of Eastern central caves. Type - holotype female.

Distribution:

Known only from type locality: Shiloh Cave, Lawrence Co., Indiana, Jan. 28, 1959, Don Burton coll.

\section{ARRHO PALITES CAECUS (Tullberg)}

Figures: $6 \mathrm{~A}, 22-25,50,52,65,81,87-89$

Sminthurus caecus Tullberg, 1871, Ofv. Kong. Vet.-Akad. 28: 146 [Type: Unknown].

Arrhopalites caecus Borner, 1906, Mitt. Naturhist. Mus. Hamburg 23: 182.

A number of specimens both from caves and epigeic localities can be identified as this species. They have striking features, the most important of these being the small spines on the anal valves, and the large ventral spine at the base of the mucro. In most respects they agree very well with the European specimens identified as this species. The differences are sometimes in conflict only with some of the descriptions available. For example, in the Nearctic specimens the dorsal dental seta $\mathrm{e}_{6}$ is absent, but Delamare and Denis indicate its presence, while Stach describes it as rarely present. In addition to this, the Nearctic specimens show seta $d_{5}$ normally displaced toward the e series even in adults, a character shown by Denis as holding for young specimens of the European forms. The series of setae $\mathrm{Ve}_{2}$ through $\mathrm{Ve}_{4}$ are very heavy in the Nearctic forms, but the figure given by Gisin 
shows a similar situation quite in contrast to that seen in the figures and descriptions of the other authors.

The spine-like setae of the head (including the IL, L and $\mathrm{M}_{3}$ ) are strikingly differentiated from the normal setae of the head. This condition is different from that described by a number of European authors; however, the Swiss and French specimens I have examined show the spine-like setae clearly. All specimens have the third antennal segment swollen, but without a distinct hump. The various descriptions merely state that no hump is present. In view of the contradictions and confusion indicated among the various European authors and the nature of the differences between the Nearctic and European forms, I feel it wisest to consider the Nearctic and European forms as synonymous until a thorough study of the European specimens can be made. At such a time it may well turn out that there are two separate species involved.

Two epigeic specimens (one from Urbana, Illinois, and one from Edmonton, Alberta) have the cephalic and dorsal spine-like setae much heavier than is seen in most of the other specimens and the female subanal appendage is apically expanded. However, in both characteristics intermediate conditions exist. In view of this and the small series of specimens seen, I feel it best to consider the forms a single species, until adequate material is available.

\section{Distribution:}

This species has been reported from many epigeic localities in North America, but the only specimens identifiable as this species seen in this study were from epigeic localities in Evey Canyon, Claremont, Calif.; Ames, Iowa; Urbana, Illinois; Edmonton, Alberta; Hunters Cave, Jackson Co., Iowa, and Wind Cave, Custer Co., South Dakota. In view of the many identifications it is best to leave the distribution entirely in doubt until new examinations of the old material can be made.

\section{ARRHO PALITES CLARUS new species}

Figures: $5 \mathrm{~A}, 7,12,40,56,66,84$

Body slightly bilaterally flattened, white or covered on dorsum and front of head and dorsum of body with scabrous patches of red pigment. Antennae with seven subsegments on fourth antennal segment. Most of the setae of fourth segment about three times as long as diameter of antennae, those of other segments $1 \frac{1}{2}$ to two times as long as the segmental diameter. Cephalic chaetotaxy with $\mathrm{M}_{1}$ always 
absent, $A_{3}$ level with posterior margin of antennae. None of cephalic or greater abdomen setae spine-like. Largest setae of anal valves not strikingly enlarged at base and about the same diameter as the subanal appendage. All ungues elongate, similar in shape. Each with a very weak median inner tooth. Mucro with weakly knobbed or spatulate tip, outer edge of mucro only irregularly and sparsely serrate, inner edge with normal regular serrations. Only one clear spine on dens $\left(E_{1}\right)$; however, the L series of setae are somewhat thicker basally, particularly $\mathrm{L}_{1}$. Ventral setae as in other members of the pygmaeus group, with $\mathrm{Ve}_{4}$ a little more than $1 / 4$ way from base to apex of dens. Tenaculum as in pygmaeus but with lateral branch or ramus somewhat shorter.

\section{Discussion:}

This is a clearly marked troglobitic species. The most striking variation to be seen in the form concerns the dental chaetotaxy. On the ventral surface the basal seta is normally as described, but on a few specimens it may be considerably nearer the base of the dens. The dorsal chaetotaxy also poses some problems in interpretation. Oñ most specimens there is only one clear spine- $\mathrm{E}_{1}$, on others both $\mathrm{E}_{1}$ and $E_{3}$ are spine-like, and in a few the $L$ series are also somewhat spine-like. However, in all such cases these structures have long apical prolongations and are clearly different from the spines found normally in these areas. There is also considerable variation in the ungues, with some specimens having a clear tunica and slight differentiation between the fore and hind ungues, but these are always similar and never so strikingly different as are those of typical pygmaeus group forms. A single specimen from Copelin Cave, Kentucky, is similar to this species in most respects; however, it differs in the basal papilla from which the subanal appendage arises and also in some small details of the dental chaetotaxy. More material is required before it can be determined if this is the same or another troglobitic species. With this exception it has been taken only from caves of Missouri and Arkansas. Types - Holotype female and five paratypes.

Distribution:

Type locality: Rockhouse Cave, Barry Co., Missouri, Sept. 7, 1959, Tecklin and Hedges coll. Also taken from Granny Dean Cave, Newton Co., Arkansas, Jan. 26, 1958, Barr coll. Wildcat Cave, Barry Co., Missouri, Sept. 7, 1959, Tecklin and Hedges coll. In addition to this there is one doubtful record of a single specimen from a cave in Kentucky (see above). 
ARRHOPALITES DIVERSUS Mills

Figures: $8,49,53,77,91,95$

Arrhopalites diversus Mills, 1934, A Monograph of the Collembola of Iowa: 93-94 [Type: Jefferson, Illinois: Ill. State Nat. Hist. Survey, Urbana].

Pseudarrhopalites diversus Stach, 1945, The Apterygoten fauna of Poland in relation to the world fauna, Family Sminthuridae, Acta Monogr. Mus. Nat., Krakow: 620.

This well marked species can be readily recognized by the unique filamentous tooth on the ungues. It is a part of the A. caecus group of the genus, as shown by the presence of small spines on the anal valves, the presence of two $\mathrm{Ve}_{3}$ setae, and the presence of a $\mathrm{Ve}_{5}$. In addition to this, it has the bulbous mucronal apex seen in many of the species of this group and has the numerous spine-like setae on the dorsum of the body characteristic of many of these forms. While there is no spine on the ventral surface of the dens, the basalmost setae are very heavy. All the relationships with the caecus group are so clear that the possession of a peculiar ungual structure can hardly be considered as meriting a special genus for the form.

The dorsal dental chaetotaxy is basically of the type seen in caecus. However, the $\mathrm{E}$ series, particularly $\mathrm{E}_{1}$ through $\mathrm{E}_{4}$ are definitely spinelike, and the same is true to a less striking degree in the $\mathrm{L}$ series. Although only three L spines and six E series setae are normally present, an additional seta or spine can be seen in some specimens of both series.

Distribution:

Type locality: Jefferson, Illinois. Also taken from Leon, Iowa; Tucson, Arizona; Coalinga, California; and Connecticut. Not reported so far from caves.

ARRHO PALITES DUBIUS new species

Figures: 5 D, 6 B, 27, 28, 48, 59, 70, 80, 92, 96

Coloration is white, with slight traces of pigment. Antennae typical of A. pygmaeus group with subsegments of fourth antennal segment clear. Third segment with clear, although not prominent, swelling at mid-level of segment. Length of longest setae on antenna, about two times diameter of antennae. Chaetotaxy of head normal with seta $\mathrm{M}_{1}$ always absent. Posterior setae $\left(\mathrm{A}_{3}, \mathrm{M}_{3^{-4}}, \mathrm{Il}_{2^{-3}}\right.$, and $\left.\mathrm{L}_{1^{-2}}\right)$ weakly spine- 
like, and difficult to distinguish from others in structure. No clear spine-like setae on body. All ungues have a prominent median inner tooth. Fore and middle empodial appendages with prominent corner tooth and apical filament longer than appendages. Hind appendage with shorter filament and extremely weak tooth. All claws with tunica. Mucro with apex weakly knobbed or flanged. Dorsal dental chaetotaxy normal except for the absence of $\mathrm{L}_{3}$. Ventral chaetotaxy with $\mathrm{Ve}_{4}$ between one fourth and one third of way from base to apex of dens. Female with subanal appendages slightly expanded apically, serrate and strikingly flattened and curved. Largest setae on anal valves very heavy, almost two times as thick as subanal appendages, and with one pair having a very minute basal flange on one side. Tenaculum as in A. pygmaeus.

\section{Discussion:}

A. dubius is obviously very close to the form here called A. pygmaeus, and future work may in fact show that it is actually a geographic variation of this species. However, the morphological differentiation is sufficient to warrant their being called separate species at the present time. The table given below shows the most striking differences seen between the two forms:

Table

\begin{tabular}{l|l|l|l}
\hline & $\begin{array}{l}\text { Female subanal } \\
\text { appendage }\end{array}$ & $\begin{array}{l}\text { Dental } \\
\text { chaetotaxy }\end{array}$ & $\begin{array}{l}\text { Third } \\
\text { antennal seg. }\end{array}$ \\
\hline $\begin{array}{l}\text { A. pygmaeus } \\
\text { A.dubius }\end{array}$ & $\begin{array}{l}\text { straight at apex } \\
\text { clearly curved } \\
\text { up at apex }\end{array}$ & $\begin{array}{l}\mathrm{L}_{3} \text { always present } \\
\mathrm{L}_{3} \text { usually absent }\end{array}$ & $\begin{array}{l}\text { swelling weak } \\
\text { swelling clear }\end{array}$ \\
\hline
\end{tabular}

In addition to this, the ratio of the fourth antennal segment to the cephalic diagonal indicates separate populations. A. dubius also varies somewhat in both dental and cephalic chaetotaxy, with occasional specimens having $\mathrm{L}_{3}$ or $\mathrm{M}_{1}$ present. However, in all such cases these setae are abnormal in position. Types - Holotype female, five paratypes.

Distribution:

Type locality: Hunters Cave, Jackson Co., Iowa. Also taken from Mystery Cave, Fillmore Co., Minnesota; Crystal Lake Cave, Dubuque Co., Iowa. 
ARRHOPALITES HIRTUS new species

Figures: 6C, 18-21, 46, 58, 72, 76, 97

Coloration: Dorsum of body, vertex and front of head covered with scabby brownish orange pigment. Thoracic intersegmental regions pale. Antennae with fourth segment having six subsegments. Third antennal segment with small but clear swelling over basal one third of structure. Antennal setae of fourth segment slightly longer than diameter of segment, those of other segments shorter than antennal diameter. Cephalic chaetotaxy normal, with $\mathrm{M}_{1}$ absent. Setae of IL and $L$ series plus $A_{3}$ weakly spiniform. No clearly spine-like setae on greater abdomen. Largest normal setae of anal valves noticeably thicker than subanal appendage, not flanged at base. Ungues each with a clear median inner tooth, but hind ungues clearly heavier and shorter than fore ungues. All empodial appendages with long apical filaments, with corner tooth striking on first two pairs and weak on third. Mucro with a weak ventral indentation and clear apical flange. Dental chaetotaxy normal except for the occasional absence of $e_{6}$. Ventral chaetotaxy of dens with $\mathrm{Ve}_{4}$ about one third of distance from base to apex of dens. Tenaculum as in pygmaeus. Female subanal appendages deeply serrate, pinnate.

\section{Discussion:}

This is a very well marked species which resembles the Japanese A. havei Yosii in some respects and the European A. ornatus in others. It can be distinguished from the former readily on a basis of the dental chaetotaxy, and from the latter by the absence of the unusual antennal hump. The species is clearly marked from the others of the genus so far seen in North America on the basis of both the female subanal appendages and the dental chaetotaxy. In the specimens examined so far, the most striking variation noted is in the number of subsegments of the fourth antennal segment. One specimen shows seven of these whereas the normal number is six. The populations from two Iowa caves show a remarkable variation in the subanal appendage of the female (see Fig. 18) with the structure appearing almost palmate in side view. This is most marked in the specimens from Wompi Cave which also have the most marked spine-like setae on the head and the most conspicuous bump on the base of the third antennal segment. In view of all this, it seems probable either that several species are included under the present definition, or that one 
species with considerable geographic variation is here to be seen. Present collections are insufficient to determine which is in fact the case, and in this situation I feel it best to consider the whole as a single variable species.

The specimens so far taken are from caves in Wisconsin and Iowa, and in a subcavernicole habitat (drainage tile) in Illinois. More adequate collections may show it to be widespread throughout the region. In addition to this, a number of collections have been seen from the west coast which are doubtful. They display most of the characteristics of the species, but those so far seen were in such poor condition that it is impossible to be certain whether a different species is in fact involved. For this reason, the species must be considered as a questionable troglophile at the present time with the peculiar distribution of cavernicole in the midwest and of epigeic in the western part of the country. It is very likely that more adequate samples will show that there are actually two species involved. Types - Holotype female, eleven paratypes.

\section{Distribution:}

Type locality: Y Cave, Maquoketa, Jackson Co., Iowa (specimens of type series taken from culture). Also taken from other caves in the Maquoketa region; Backbone Cave, Delaware County; and Wompi and Thurn Caves, Clayton County; Dance Hall Cave, Jackson County; and four caves in Wisconsin: Jenkins Cave, Pierce Co.; Rising Sun Cave, Pierce Co.; John Gray and Pop's Cave, Richland Co.; all in August 1958. Also taken from drainage tile, Union Co., Illinois, and from the vicinity of Indian Lake, Ohio. Three doubtful epigeic localities are Logan Co., Utah; Claremont, Calif.; and Corvallis, Oregon.

\section{ARRHOPALITESAMARUS new species}

Figures: 26, 43, 57, 73, 90, 93

Antennae with fourth segment having five subsegments. Third segment with gradual enlargement at base. Longest setae of third and fourth antennal segments only slightly longer than the diameter of the antennae. Cephalic chaetotaxy normal with $\mathrm{M}_{1}$ missing. Cephalic spine-like setae very heavily swollen basally on setae $A, I_{1}, I_{2}$, and $\mathrm{L}_{1}$. Thoracic setae of first two rows heavy and spine-like. Largest setae on anal valves heavy, clearly thicker than subanal appendages and with small but striking basal, serrate flanges. Fore and hind ungues 
each with a minute, unclear, inner median tooth. Mucro with apical knob or flange and sharp indentation about two-thirds of the way from the base to the apex of the ventral surface. Chaetotaxy of dorsum of dens unusual in that setae $\mathrm{L}_{2}, \mathrm{~L}_{3}$, and $\mathrm{E}_{3}$ are all very weakly spiniform and difficult to distinguish from the normal body setae. This is particularly true of $\mathrm{E}_{3}$, which can be considered in most cases as a normal dental seta. $\mathrm{Ve}_{4}$ is about one-third of the distance from the base to the apex of the dens. The tenaculum is normal, and the female subanal appendage is short and acuminate with a heavy unilateral flange near the apex.

\section{Discussion:}

Only a small series (five specimens) of this species has been examined; however, the subanal appendages and the seta-like nature of $e_{3}$ of the dental setae are combined with the spine-like setae of the first two rows of thoracic setae to make this a well marked species. A single very large specimen has been seen, and on this the $L$ series of dental setae are considerably more spine-like than on the other specimens. More material must be examined before it can be determined whether this is a normal development in post-maturity molts in the group. At the same time, the small basal flanges on the largest setae of the subanal valves can be seen on normal specimens only with some difficulty, but they are very striking on the one extra-large animal. All of the cephalic setae of the numbered series are somewhat spinelike, but the ones of the I L series, as well as $A_{3}$ and $L_{1}$ are very striking and about the heaviest cephalic spines seen in the genus in North America. I have examined the types of Gisin's A. cochleafer, which resemble A. amarus strikingly in the shape of cephalic spines and to some extent in the shape of the mucro. While the two species do present many familiar features, $\mathrm{L}_{2}$ and $\mathrm{L}_{3}$ are clearly more spine-like in $A$. cochleafer and $\mathrm{E}_{3}$ and $\mathrm{E}_{4}$ are clearly heavier and more spine-like in A. cochleafer than in A. amarus. The subsegments of the fourth antennal segment are different, six in cochleafer and five in amarus. Type - Holotype female, Ill. State Nat. Hist. Survey, Urbana.

\section{Distribution:}

The species so far has been recorded from only three epigeic localities. Type locality: Volo, Illinois, \# 49748 Richards \& Sanderson coll. Also taken from Charleston, Ill., Rocks Park, Oct. 2, 1946, Ross and Sanderson coll.; and Evey Canyon, 4 mi. NNE Claremont, California, March 12, 1953, R. Benjamin coll.; Arnprior, Ontario, Canada; Carter Basin, Labrador, Sept. 7, 1958, Lawrence coll. 


\section{ARRHO PALI TES PYGMAEUS (Wankel)}

Figures: 3, 4, 32-34, 47, 78, 85, 101

Dicyrtoma pygmaeus Wankel, 1860, Lotos, Zeitschrift f. Naturwissenschaft 10: 201 .

Smynthurus ferrugineus Packard, 1888, Mem. Nat. Acad. Sci. 4: 67 [Type: New Market cave, Rockingham Co., Va.; Mus. Comp. Zool.]. New synonymy.

Smynthurus mammouthia Banks, 1897, Amer. Nat. 31: 381 [Type: Mammoth cave Edmonson Co., Ky. U.S. Nat. Mus.]. New synonymy.

Sminthurinus binoculatus Borner, 1901, Zool. Anz. 23: 343 [Type: Lemathe Cave, Westfalia].

Arrhopalites pygmaeus: Stach, 1945, Academia Polona Litterarum et Scientarum Acta Musei Historia Naturalis 1: 30-34.

The Nearctic members of this species are indistinguishable from the European members of the species using the present basis of the taxonomy. For this reason, I am considering them as synonyms for the moment, in spite of the fact that future work may well show that one or more separable Nearctic forms exist.

The structure of the Nearctic specimens is quite variable in a number of characteristics. The tunica may be clearly present on all ungues, absent on one pair, or not visible at all. The ratio between the first subsegment of the fourth antennal segment and the third antennal segment is variable, but there is no basic distinction which can be made here, either between the epigeic and cave forms or between the European and Nearctic forms. The subanal appendages of the female also vary a great deal, most strikingly in caves of Missouri and Northern Tennessee (see Fig. 34\& 35), but the variation in this structure is in no way congruent with the variation in the other characteristics. Variation in antennal structures occurs in specific regions. In two caves, Ash Cave, Pulaski Co., Missouri, and Godwin Cave, Maury Co., Tennessee, specimens are found with six rather than five subsegments on the fourth antennal segment, while in Claiborne Co., Tennessee, the third antennal segment is noticeably enlarged basally.

In contrast to these structures the chaetotaxy of the head and of the dens is quite constant. On the head, seta $M_{1}$ is almost always absent, and none of the setae is strikingly spiniform. The posterior setae are somewhat heavier than the anterior ones (particularly $\mathrm{IL}_{2}$, $\mathrm{IL}_{3}$, and $\mathrm{L}_{2}$ ), but this is never striking and can easily be overlooked. The dorsal setae of the dens are quite normal (see Table 1), while the ventral setae have $\mathrm{Ve}_{4}$ about one third of the way from the base to the apex. The spine-like setae of the dens are constant in number, but they vary slightly in shape, sometimes being clearly spines and other times having a slender apical filament and being somewhat seta-form. 
The largest setae of the anal valves are slightly thicker than the subanal appendages and either without flanges or with a very minute flange on one pair. The tooth structure of the unguis is quite constant, but the empodial appendage may have the typical corner tooth absent. In short, this appears to be an extremely variable species within North American caves. The exact nature of this variation must await further work, but much of it appears to be geographic in nature.

I have examined the type specimens of both A. mammouthia and of A. ferrugineus. In both cases there does not appear to be any characteristic which would serve to separate these species from each other, or from the typical A. pygmaeus of North America. Packard, in his description and figures of ferrugineus, shows the presence of seven subsegments on the fourth antennal segment; however, the type specimen clearly shows that this is not so, and the typical five subsegments are in fact present. In both species the type specimens clearly show the subanal appendages of the female, and these are of the typical pygmaeus type. In view of all these facts I am considering both species as synonyms of pygmaeus.

\section{Distribution:}

This form is extremely rare as an epigeic animal but quite common in caves. The cave distribution shows the typical widespread type being found in Virginia; the Tennessee, Kentucky, Alabama area; and in Missouri and Northern Arkansas. It does not appear in the north central caves, where it is replaced by A. dubius. A number of the epigeic finds were in such places (drain tiles) as to make it likely that this is in fact a troglobitic form still retaining some tolerance for outside conditions. Kentucky: Mt. Olive in the vicinity of Lexington; Mammoth Cave, Edmonson Co.; Arkansas: Devil's Den, Devil's Den State Park, Wash. Co., Cave on expanded joint, from wood on floor; Brewer Cave near Everton; Tennessee: Wall Cave, Putnam Co., Jan. 4, 1961, Barr coll.; Godwins Cave, Maury Co., June 8, 1957, Barr coll.; Ward Cave, Bedford Co., Aug. 27, 1957, Barr coll.; Foster's Cave, Montgomery Co., inside cave, beneath rocks and sticks; Durham's. Cave, Montgomery Co.; Cumberland Caverns, Warren Co.; Hargis Cave, 1 mi. north Granville, Jackson Co.; Virginia: Madison Cave, Bath Co., Aug. 27, 1958, Barr coll.; Fraley's Cave, Wyndale 71/2' Quad.; Missouri: Fisher Cave, Franklin Co., Feb. 8, 1958, Tecklin coll.; Bat Cave, Pulaski Co., near Crocker, Feb. 14, 1959; Powder Mill Creek Cave, Shannon Co.; Old Spanish Cave, Stone Co.; Marcellus Cave, Phelps Co.; Wildcat Cave, Barry Co.; across field from Rockhouse 
Cave; Ash Cave, Pulaski Co.; Alabama: Simmons Cave 4 mi. N.W. Huntsville, Madison Co., 11-10, 1961; Illinois: Charleston, Rocks Park, debris about spring; Florida: Gainesville, Alachua Co.

\section{ARRHOPALITES WHITESIDEI Jacot}

Figures: 14-17, 45, 54, 67, 79, 86, 102

Arrhopalites whitesidei Jacot, 1933, Amer. Mid. Nat. 20: 572-573 [Type: Branford Conn.; State Agricultural Exp. Stat. New Haven, Conn.].

Body normal in shape, antennae with five subsegments on fourth antennal segment. Longest setae of third and fourth segments about twice as long as diameter of segments. Cephalic chaetotaxy with seta $\mathrm{M}_{1}$ always absent, setae of $\mathrm{L}$ and IL series clearly spine-like, those of $\mathrm{M}$ and A series weakly so. Chaetotaxy of thorax with first row of setae weakly spiniform, remainder normal. Anal valves with largest setae strikingly thicker than subanal appendages and with two or more bearing a weak, serrate flange at one side of base. Eyes not prominent and can frequently be seen only as smooth areas in the integument. Claws with the anterior pair strikingly more slender than the posterior pair. Ungues clearly tunicate and with a striking median tooth. Mucro with clear apical knob or large flange. Chaetotaxy of dens normàl for pygmaeus group except for the absence of seta $\mathrm{Id}_{3}$. Ventral setae with $\mathrm{Ve}_{4}$ about one third of distance from base to apex of dens. Tenaculum normal. Subanal appendage long, slender, strikingly curved and acuminate with one or more deep serrations along margin.

Discussion:

This species is common in caves over a wide area, and a rare species in epigeic habitats over an equally wide front. I have examined the types of Jacot's species and have found them to be the same as the form described above. The species is clearly marked on the basis of the dental chaetotaxy and the curved acuminate subanal appendage. The female subanal appendage is quite variable. The appendage may be almost entirely smooth, or equipped with a few scattered serrations, or serrate over the whole length of both margins. In all cases the rod is long, acuminate, and markedly upcurved. Another variable characteristic of the species is the eye. In most forms a single pair of eyes is clearly present, but in many specimens the eyes have no pigment patch, and can be seen as vestigial (?) cornea only under careful examination of the eye region with very high magnification. The flanged setae described for the anal valves are frequently very weakly developed and may be absent. 
Distribution:

This appears to be a primarily epigean species which has invaded caves in widely dispersed localities. Type locality: Ant nest, Branford, Conn., March 1937; other epigeic localities: Keeseville, N. Y., Aug. 25, 1956, Stannard coll.; numerous localities in central and Southern Illinois; Evey Canyon, Los Angeles County, California. Cave localities: Crystal Cave, Spring Valley, Pierce Co., Wisconsin, Aug. 4, 1958; Lewis cave, Ripley Co., Missouri, Sept. 11, 1959, Tecklin and Hedges coll.; Muenster cave, Dubuque Co., Iowa, Nov. 11, 1959; Kymulga Cave, Talladega County, Alabama, July 6, 1951; Sullivan Cave, Lawrence Co., Indiana; Crystal Lake Cave, Dubuque Co., Iowa, 1958.

\section{COLLOPHORA QUADRIOCULATUS (Denis)}

Figures: 9, 10, 11

Arrhopalites quadrioculatus Denis, 1933, Boll. Lab. Zool. Portici 25: 284-285

[Type: Serrin Viejo, Santa Rosa, Costa Rica].

Collophora quadrioculatus Delamare-Massoud, 1964, Zool. Anz. 172: 34.

This remarkable species is probably primarily a tropical form, and it is quite distinct from all of the Arrhopalites seen in North America. In many respects it resembles Pararrhopalites of Bonet; however the ventral tube appears to be smooth rather than warty. The most striking features of the species are the numerous eyes, the absence of clear spines on the dens, and the presence of a peculiar knobbed bothriotrichia on the great abdomen. This last feature was seen on both the one specimen taken from the U.S. and several of the type series of specimens from Costa Rica. In any case, the species is readily distinguished both on dental chaetotaxy and eye number, and is apparently unrelated to the other forms seen here.

Only one specimen from the U.S. was seen, and this was taken from Cochise Co., Arizona.

\section{SUMMARY}

The members of the genus Arrhopalites (Collembola Sminthuridae) found in the U.S. and Canada are described and illustrated. These include six previously described forms and seven new species: $A$. altus, A. clarus, $A$. bimus, A. bellingeri, A. dubius, A. hirtus, and A. amarus. Two forms known only from incomplete specimens are described, but not named. Nine of the species are found in caves, but only four of these are at present unknown from surface localities. The characteristics of the genus are described and discussed, and the genus Pseudarrhopalites Stach is placed in synonymy with Arrhopalites. New methods are developed for formulazing the structure of the female subanal appendage, and identifying the cephalic spines and setae. 


\section{SOMMAIRE}

Les membres du genre Arrhopalites (Collembola Sminthuridae) trouves au E. U.A. et au Canada sont décrits et dessinés. Sont comprises six formes décrites précédemment et sept espèces nouvelles :A. altus, A.clarus, A.bimus, A. bellingeri, $A$.dubius, $A$. hirtus et $A$. amarus. Deux formes connues uniquement d'après des spécimens incomplets sont décrits, mais sans nom. Neuf d'entre les espèces se trouvent dans les cavernes, dont quatre seulement inconnues à présent comme provenant de localités de surface. Les caractéristiques du genre sont décrits et discutés et le genre Pseudarrhopalites Stach est rangé en synonymie avec Arrhopalites. Des méthodes nouvelles ont été développées pour réduire en formules la structure de l'appendice anal de la femelle et pour identifier les épines céphaliques et les soies.

\section{REFERENCES}

The listing below includes most of the works of significance for studies in this genus. Those works marked with an asterisk are of primary importance.

Agrell, I. (1939) - Zur. Kenntnis der schwedischen Collembolen mit Beschreibung von vier neuen Arten und einigen Varietäten. Opusc. entomol., 4: 159-168.

- (1941) - Zur Ökologie der Collembolenuntersuchungen im schwedischen Lappland. Ibid., Vol. III, Suppl. 3: 1-236.

- (1943) - Kritisches Verzeichnis der schwedischen Collembolen mit einigen Neubeschreibungen und tiergeographischen Erörterungen. Ibid., 8: 123-137.

- (1948) - Studies on the postembryonic development of Collembola. Ark. Zool., (A), 41 (12): 1-35.

Banks, N. (1897) - Descriptions of two new Smynthurids. Jour. New York Entomol. Soc., 5: 33-34.

Bellinger, P. (1954) - Studies of soil fauna with special reference to the Collembola. Bull. Connecticut Agric. Exp. Stat., 583: 1-67.

Bodvarsson, H. (1957) - Apterygota. The Zoology of Iceland. Vol. III (37).

*Borner, C. (1906) - Das System der Collembolen nebst Beschreibung neuer Collembolen des Hamburger Naturhistorischen Museums. Mitt. Naturh. Mus. Hamburg, 23: 147-188.

Cassagnau, P. (1961) - Ecologie du sol dans les Pyrénées centrales - Les biocénoses de Collemboles. Problèmes d'Ecologie - Cahiers de Géobiologie et d'Ecologie: 1-235.

Cassagnau, P., and Delamare-Déboutteville, C. (1955) - Mission Henri Coiffait du Liban (1951) 3. Collemboles. Biospeleologica, 75: 365-395.

*_ (1953) - Les Arrhopalites d'Europe. Notes Biosp., 8: 133-147.

Christiansen, K. (1960) - A preliminary survey of the knowledge of North American cave Collembola. American Midl. Nat., 64: 39-44.

Copeland, T. P. (1960) - A preliminary list of the Collembola of East Tennessee. Jour. Tennessee Acad. Sci., 35 (4) : 238-243. 
Da Gama, M. M. (1959) - Contribuiçao para estudo dos colembolos do Arquipelago da Madeira. Memorias e Estudos do Museu Zool. Univ. Coimbra N., 257: 1-42.

- (1959) - Contribuçao para o estudo dos Colembolos de Portugal Continental. Ibid., N., 260: 1-33.

- (1961) - Nouvelle contribution pour l'étude des Collemboles du Portugal Continental. Ibid., N., 274: 1-20.

Delamare-Déboutteville, C. (1944) - Collemboles Cavernicoles du Portugal recoltés par A. De Barros Machado. Rév. française d'Entomologie, $13(3): 100-104$.

*Delamare-Déboutteville, C., and Massoud, Z. (1964) - Collophora remanei n. sp. Collembole Sympypléone du Pérou et remarques sur le genre Collophora Richards et sa position systématique. Zool. Anz., $172(1)$ : $29-36$.

Denis, J. R. (1931, 1933) - Contributo alla conoscenza del "Microgenton" di Costa Rica. Boll. Lab. Zool. Portici, Part I-25: 69-170, Part II-27: $222-322$.

— (1938) - Collemboles d'Italie. Boll. Soc. Adriatica di Sci. Nat., Trieste, $36: 95-165$.

*- (1947) - Sur la faune française des Aptérygotes (XXIVe Note). I. Etude du materiel récolté en Corse. Ann. Sci. Nat., Zool. 11e série, 9: 1-12.

Folsom, J. W. (1896) - New Sminthuri etc. Psyche 7: 446-450.

Gisin, Hermann (1943) - Ökologie und Lebensgemeinschaften der Collembolen im schweizerischen Exkursionsgebiet Basels. Rev. suisse zool., $50(4): 131-224$.

- (1944) - Hilfstabellen zum Bestimmen der holarktischen Collembolen. Verh. naturf. Ges. Basel, 55: 1-130.

- (1944) - Materialien zur Revision der Collembolen. II. Weiteres Basler Material. Mitt. d. Schweizerischen Entomol. Ges., 19: 121-156.

- (1947) - Sur les insects Aptérygotes du Parc National Suisse. Untersuch. d. schweiz. Nat. Pks., S. N., 2: 77-90.

- (1955) - Recherches sur la rélation entre la faune endogée de Collemboles et les qualités agrologiques de sols viticoles. Rev. Suisse zool., 62: 601-648.

- (1958) - Sur la fauna européenne des Collemboles. Ibid., 65 (36) : 773-778.

- (1960) - Collemboles cavernicoles de la Suisse, du Jura français, de la Haute-Savoie et de la Bourgogne. Ibid., 67: 309-322.

- (1960) - Collembolenfauna Europas. $312 \mathrm{pp}$.

Hammer, Marie (1937) - A quantitative and qualitative investigation of the microfauna communities of the soil at Angmagssalik and in Mikis Fjord. Meddelelser Om Grønland Udgivne af Kommissionen For Videnskabelige Undersøgelesser I Grøn., 108 (2): 1-53.

- (1938) - The Zoology of East Greenland. Ibid., 121 (2) : 1-42.

- (1953) - Investigations on the Micro-Fauna of Northern Canada (Part II). Acta Arctica, 6: 1-108.

HandSGHin, Ed UARD (1924) - Ökologische und biologische Beobachtungen an der Collembolenfauna des schweizerischen Nat.-Pks. Verh. Naturf. Ges. Basel, 35: 71-101. 
Handschin, Eduard (1926) - Subterrane Collembolengesellschaften. Ark. für Naturg., 91: 119-138.

- (1927) - Die Ökologie der Collembolenfauna westfälischer Hochmoore. Zeitsch. f. wiss. Ins.-Biol., 31: 295-310.

НА у васн, G. (1959) - Über die Collembolenfauna verschiedener Waldböden. Verh. d. Zool.-Botan. Ges. Wien, 98: 31-51.

$\mathrm{J}_{\mathrm{Acot}}$ P. A. (1938) - Four New Arthropoda from New England. American Mid. Nat., 20: 571-574.

Lawrence, P. (1959) - Cavernicolous Collembola Collections. Trans. Cave Res. Gr. Great Britain, 5: 115-131.

Linnaniemi, W. (1912) - Die Apterygotenfauna Finnlands. II - Spezieller Teil. Acta Soc. Sci. Fennicae, 40: 1-359.

LoksA, L. (1956) - Die zoologische Untersuchung von Collembolen in einer ungarischen Querceto-Pottentilletum-Albae-Assoziation. Acta Zool., 2: 199-243.

Maynard, E. (1951) - The Collembola of New York State, 339 pp.

Mills, H. (1934) - A monograph of the Collembola of Iowa, 143 pp. Collegiate Press, Ames, Iowa.

Nicholas, G. (1960) - Checklist of Macroscopic Troglobitic Organisms of the U.S. American Midl. Nat., 64 (1) : 123-160.

Packard, A. S. (1888) - The cave fauna of North America. Mem. Nat. Acad. Sci., 4: 1-156.

Scott, D. (1942) - Some Collembola Records for the Pacific Coast and a Description of a New Species. Pan-Pacific Entomol., 18 (4) : 177-186.

Scotт, H. (1961) - Collembola: Pictorial Keys to the Nearctic Genera. Ann. Entomol. Soc. America, 54 (1) : 104-113.

*Stach, J. (1945) - The species of the genus Arrhopalites occurring in European caves. Academia Polona Litterarum et Scientiarum Acta Musei Historiae Naturalis, 1: 1-47.

* - (1956) - The Apterygote Fauna of Poland in Relation to the World Fauna of the Group of Insects: Family Sminthuridae. Polska Akademia Nauk, 1-287.

- (1959) - Fauna Apterygota Polskiego Narodowego Parku Tatrzanskiego. Acta Zool. Cracoviensia, 4 (1) : 1-102.

Strebel, Отто (1957) - Ein Beitrag zur Faunistik und Biologie der Apterygoten aus einem Zuckerrübenfeld in der Oberrheinischen Tiefebene. Ibid., 2: 469-478.

- (1959) - 6. Die Apterygoten-Fauna des Siebengebirges. A. Die Collembolen in den Stollen der Ofenkaule, Siebengebirge und Rodderberg. Beiträge zur Biologie eines rheinischen Naturschutzgebietes. Decheniana, $\%: 91-97$.

Tullberg, T. F. (1871) - Forteckning ofver Svenska Podurider. Ofv. Kongl. Vet.-Akad. Forh., 28: 143-155.

Wankel, H. (1860) - Beiträge zu mährischen Höhlen. Lotos, 10: 202.

WEBER, N. (1940) - A survey of the insects and related Arthropods of Arctic Alaska. Trans. Am. Entomol. Soc., 76: 163-170. 
Womersley, H. (1937) - New species and records of Australian Collembola. Trans. Roy. Soc. S. Australia, 61: 154-157.

- (1939) - Primitive Insects of South Australia, $322 \mathrm{pp}$.

Wray, D. (1950) - Insects of North Carolina. Second Supplement, 5-8.

Wray, D., and Knowlton (1953) - Additions to the List of the Collembola of Utah. Great Basin Nat., 8 (1-2): 43-46.

Yosır, R. (1954) - Höhlencollembolen Japans. I. Kontyu, 20 (3-4) : 62-69. - (1954) - Springschwänze des Oze-Naturschutzgebietes. Sci. Research. of the Ozegahara Moor., 777-830.

- (1955) - Meeresinsekten der Tokara-Inseln. VI. Collembolen nebst Beschreibungen terrestrischer Formen. Publ. Seto Mar. Biol. Lab. IV $(2-3): 381-401$.

- (1956) - Monographie zu Höhlencollembolen Japans. Contr. Biol. Lab. Kyoto U. (3) : 1-109.

\section{EXPLANATIONS OF PLATES $\left.11(1)-19(9)^{1}\right)$ PLATE $11(1)$}

General features of genus.

Figures 2-4: Chaetotaxy of various organs showing lettering systems. 2. Dorsum of head, semi-diagrammatic. 3. Dorsum of dens of pygmaeus. 4. Venter of dens pygmaeus. 5. Series of $\mathrm{L}_{2}$ spines showing the variation seen in this structure: A. clarus; B. benitus from Parsons, Tenn.; C. benitus from Annisquam, Mass.; D. dubius. 6. Series of mucrones showing different types: A. Bulbed tips deeply indented ventral surface, (caecus); B. Flanged tip slightly indented ventral surface, (dubius); C. Pointed tip straight ventral surface, (hirtus). 7. Typical habitus (setae omitted) form illustrated clarus $30 \times$.

\section{PLATE $12(2)$}

Female subanal appendages, seen from above and to one side with a magnification of about $3,000 \times$ except where otherwise stated.

8. diversus, Tucson, Arizona. Figures 9-11: Collophora quadrioculatus. $9 \& 10$. Two different specimens same locality, Yucatan. 11. Side view, Tucson, Arizona. 12. clarus, Copelin Cave, Ky., 1,000×.13. altus, holotype. Figures 14-17: whitesidei. 14. Kymulga Cave, Childersburg, Ala. 15. Jordan Creek, Vermillion Co., Ill. 16 \& 17. Bell Smith Springs, Ill., two different specimens same locality. Figures 18-21: hirtus. 18. Wompi Cave Clayton Co., Iowa. 19. Arnprior, Ontario. 20. Logan Canyon, Utah. 21. Longhorn Caverns, Burnet Co., Texas. Figures 22-25: caecus. 22. Culture originating from Hunters Cave, Jackson Co., Iowa. 23. Edmonton, Alberta. 24. Urbana, IIl. 25. Evey Canyon vic., Clarmont, Calif. 26. amarus, Volo, Ill. Figures 27 \& 28: dubius. 27. Hunters Cave, Jackson Co., Iowa. 28. Same seen from side. 29. sp.? Veiled Lady Cave, Penn. 30. sp.? Griffin Creek area, Jackson Co., Ore. 31. bimus, Shiloh Cave, Lawrence Co., Ind. Figures 32-34: pygmaeus. 32. Typical form, Scott Cave, Madison Co., Ala. 33. Unusual form, Station Creek Cave, Claiborne Co., Tenn. 34. Unusual form, Leesburg, Fla. 35. bellingeri, Schofield Pass, Colo. Figures 36-38: benitus. 36. Breezewood, Pa. (seen from below). 37. Volo, Ill. (seen from side). 38. Type specimen (seen from below).

\footnotetext{
1) All species Arrhopalites unless otherwise noted.
} 
PLATE $13(3)$

Ungues and empodial appendages. In each species the forefoot is lettered A and the hindfoot is lettered B. Magnification about $1,000 \times$ except as noted.

39. altus, holotype. 40. clarus, A. forefoot paratype, B. hindfoot holotype. 41. bimus, holotype, $500 \times$. 42. bellingeri, holotype, $3,000 \times$. 43. amarus, holotype, 3,000 $\times$. 44. benitus, Parsons, Tenn., 3,000 ×. 45. whitesidei, A. forefoot, Lowmoor Quarry Cave, Alleghany Co., Va., B. hindfoot, Kymulga Cave, Childersburg, Ala. 46. hirtus, Pops Cave, Richland Co., Wisc. 47. pygmaeus, A. forefoot Madison Cave, Augusta Co., Va., B. hindfoot Brewer Cave, Everton, Ark. 48. dubius, A. forefoot holotype, B. hindfoot paratype. 49. diversus, Tucson, Arizona, $3,000 \times$.50. caecus, Urbana, Ill., $3,000 \times$.

\section{PLATE 14 (4)}

Dental Chaetotaxy. In each case the dorsal surface is marked A. and the ventral surface is marked B. Specimen seen from above or below except where otherwise noted.

51. bellingeri, holotype, $250 \times$. 52. caecus, culture origin Hunters Cave, Jackson Co., Iowa, 1,500 ×. 53. diversus, Coalinga, Calif., $500 \times .54$. whitesidei, Jordan Creek, Vermilion Co., Ill., $500 \times .55$. benitus, A. Crailhope, Ky., B. Boston Bar, British Columbia, $500 \times .56$. clarus, holotype, seen from side, $250 \times .57$. amarus, Volo, Ill., 1,500 ×. 58. hirtus, $\mathrm{A}_{1}$. Wompi Cave, Clayton Co., Iowa, $250 \times, \mathrm{A}_{2}$. Dance Hall Cave, Jackson Co., Iowa, $500 \times$, both specimens seen from side, B. Star Valley Cave, Crawford Co., Wisc., $500 \times$. 59. dubius, holotype, $500 \times$. 60. altus, holotype, seen from side only basalmost ventral seta shown, $250 \times .61$. bimus, holotype, seen from side, $500 \times$.

\section{PLATE $15(5)$}

Cephalic chaetotaxy, and antennal form.

Figures 62-64: benitus, variations of spine distribution on posterior portion of left half of head, as seen from above. All figures about $500 \times$. 62. Volo, Ill. 63. Arnprior, Ontario. 64. Apaican, Costa Rica. Figures 65-72: third and fourth antennal segments with setae omitted. 65. caecus, culture derived from Hunters Cave, Jackson Co., Iowa, 1,000×. 66. clarus, Granny Dean Cave, Washington Co., Ark., $250 \times$. 67. whitesidei, Jordan Creek, Vermilion Co., Ill., $250 \times$.68. bimus, holotype, $250 \times$. 69. altus, holotype, $250 \times$. 70. dubius, Hunters Cave, Jackson Co., Iowa, $500 \times .70 \mathrm{~A}$. Third segment dubius, holotype, $500 \times .71$. benitus, Parsons, Tenn., $500 \times .72$. hirtus, Wompi Cave, Clayton Co., Iowa, $250 \times .72 \mathrm{~A}$. hirtus, same locality, $250 \times$. Figures 73-84: Spine like cephalic seta (lettered B et. seq.) and normal interantennal seta (lettered A). Magnification about 3,000 $\times 73$. amarus, Arnprior, Ontario. 74. benitus, A.B. Volo, Ill.; C. Edmonton, Alberta; D. Bell Smith Springs, Ill. 75. bellingeri, holotype. 76. hirtus, Wompi Cave, Clayton Co., Iowa. 77. diversus, Homer, Ill. 78. pygmaeus, Wall Cave, Putnam Co., Tenn. 79. whitesidei, Jordan Creek, Vermilion Co., Ill. 80. dubius, Hunters Cave, Jackson Co., Iowa. 81. caecus, A.\& B. Wind Cave, Custer Co., S. D.; C. Edmonton, Alberta. 82. bimus, holotype. 83. altus, holotype. 84. clarus, paratype. 


\section{PLATE 16 (6)}

Anal setae, mucrones, and misc.

Figures 85-91: Anal setae, about 3,000 $\times$, except where noted. 85. pygmaeus, Muenster Cave, Dubuque Co., Iowa, 1,000 ×. 86. whitesidei, Kymulga Cave, Childerburg, Ala., 250×. 87-89. caecus: 87. Culture derived from Hunters Cave, Jackson Co., Iowa. 88 \& 89. Different specimens Edmonton, Alberta. 90. amarus, Charleston, Ill. 91. diversus, Homer, Ill. Figures 92-96: Mucrones seen from side. 92. dubius, Hunters Cave, Jackson Co., Iowa, $250 \times$. 93. amarus, Volo, Ill., 1,500×. 94. bimus, paratype, $500 \times .95$. diversus, Homer, Ill., 1,500 ×. 96. dubius, Fosters Cave, Montgomery Co., Tenn., $250 \times .97$. Female subanal appendage specimen from Jackson Co., Ore., doubtfully identified as hirtus, $3,000 \times .98 \& 99$. Eyes of two different paratypes, bellingeri, $3,000 \times .100$. Tenaculum, altus, holotype, 1,500 $\times$. 101. Tenaculum, pygmaeus, Wall Cave, Putnam Co., Tenn., 3,000 ×. 102. Spine $\mathrm{L}_{2}$ whitesidei, Jordan Creek, Vermilion Co., Ill., 3,000 × .

\section{PLATE 17 (7)}

Curves for four different organ ratios, each curve being a composite for all species except $A$. clarus, which is shown as a dotted line connected to the appropriate black curve. In the key below the ordinate is given first in each case. A : cephalic diagonal/fourth antennal segment; B : mucro/dens; G: fore tibiotarsus/hind tibiotarsus; D : mucro/fore unguis.

\section{PLATE 18 (8)}

Top: Curves showing change in ratio of first subsegment of the fourth antennal segment (ordinate) to the cephalic diagonal (axis). A: altus and clarus; B: whitesidei; C: pygmaeus; D: composite of dubius, hirtus, and benitus.

Bottom: Curve showing ratio between Cephalic diagonal (Ordinate), and hind tibiotarsus (axis).

\section{PLATE 19 (9)}

Matrix representing variation found in female subanal appendages in Holarctic Arrhopalites. In the center a simple form is represented, and all others are considered as variations from this. The most highly differentiated are represented as points along the periphery, and in each case the form considered as a midway intermediate is also illustrated. The radii of differentiation are numbered, and the level of differentiation is represented by lettered concentric circles. 

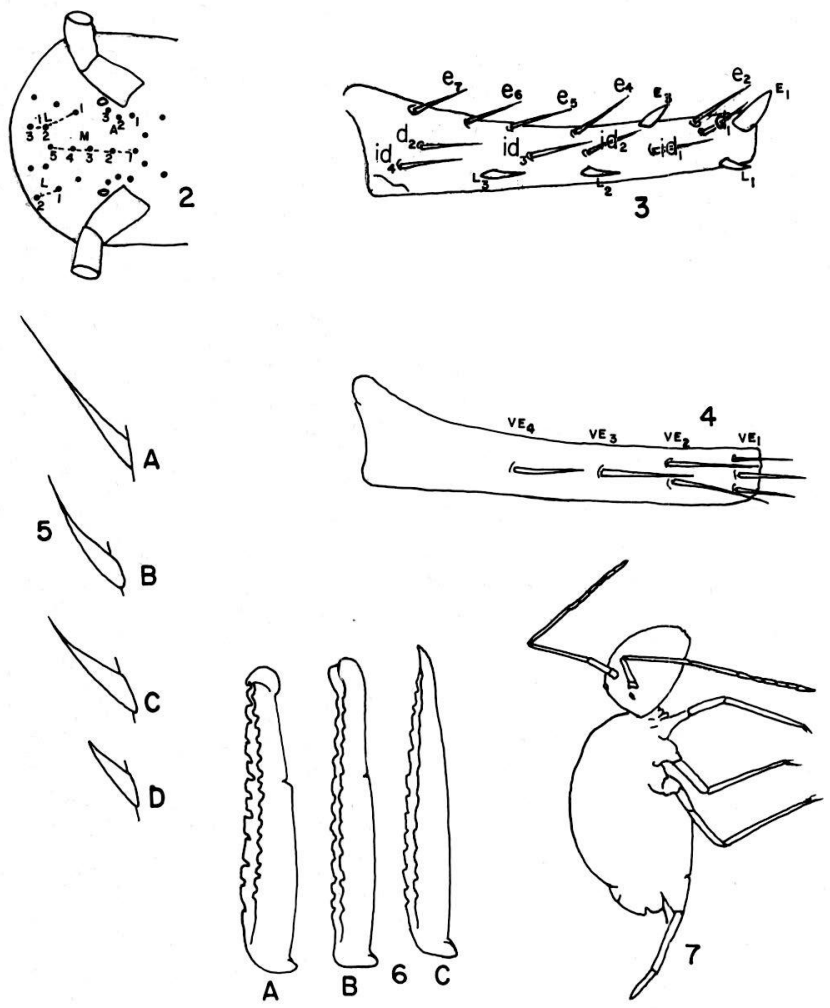

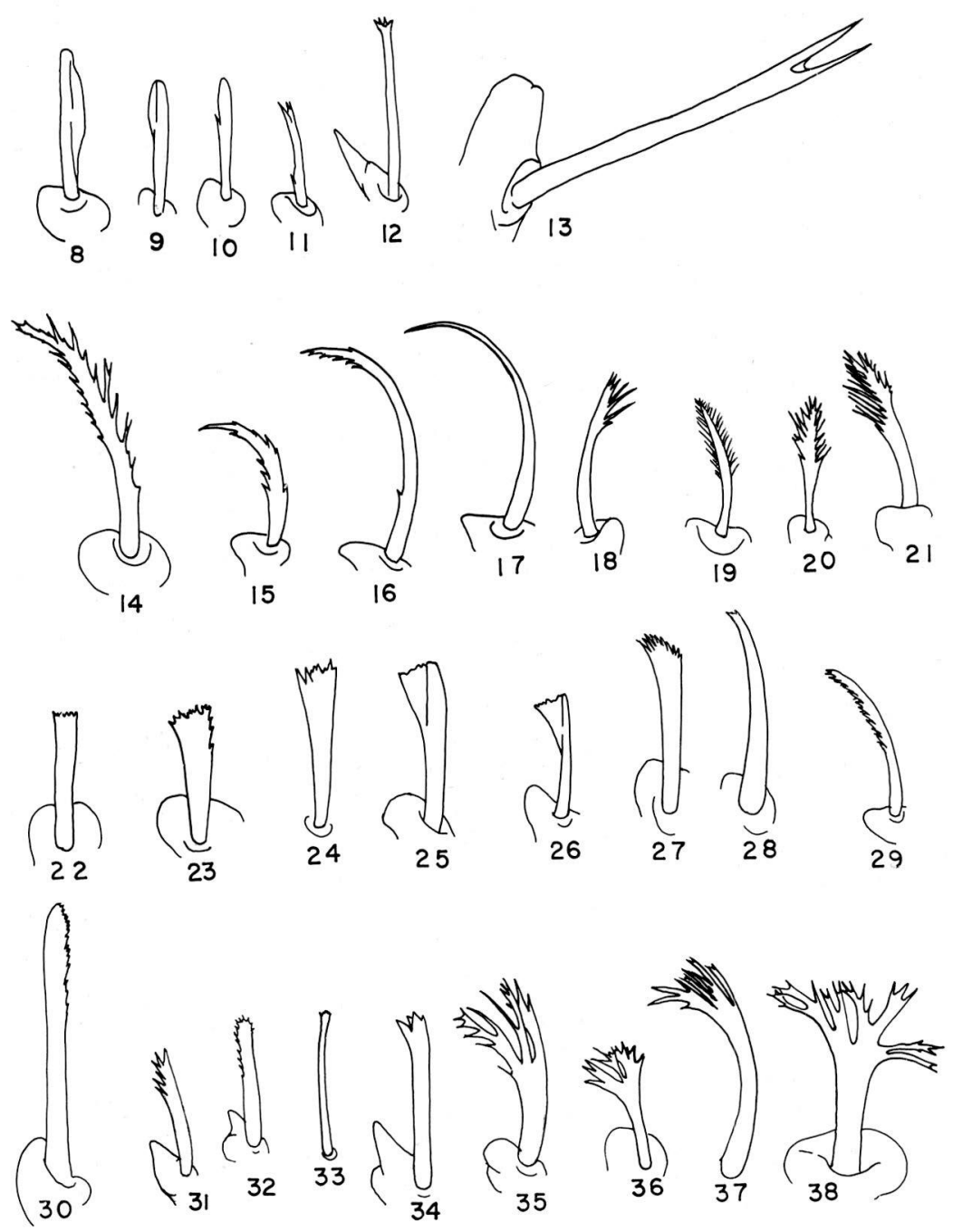


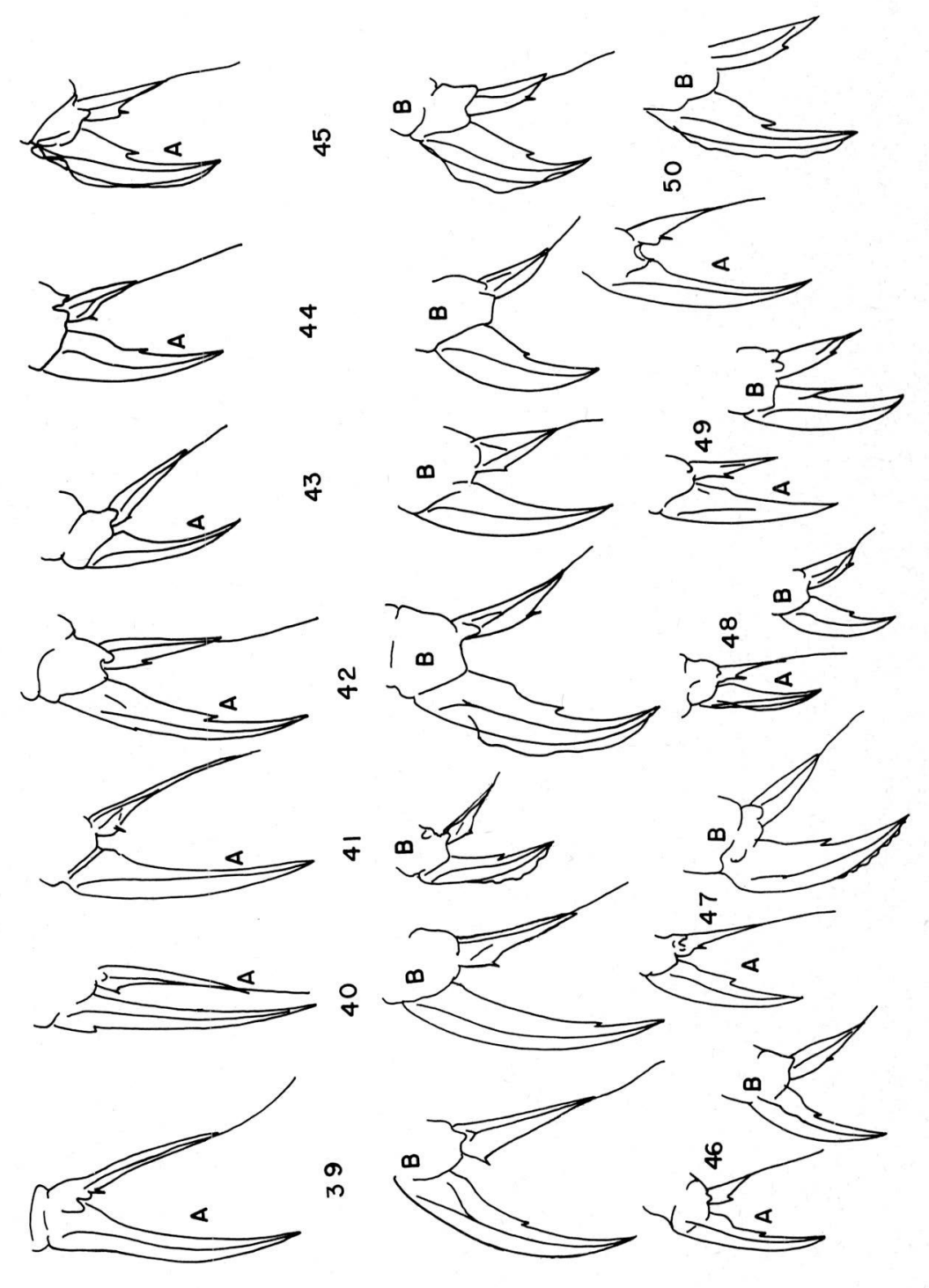




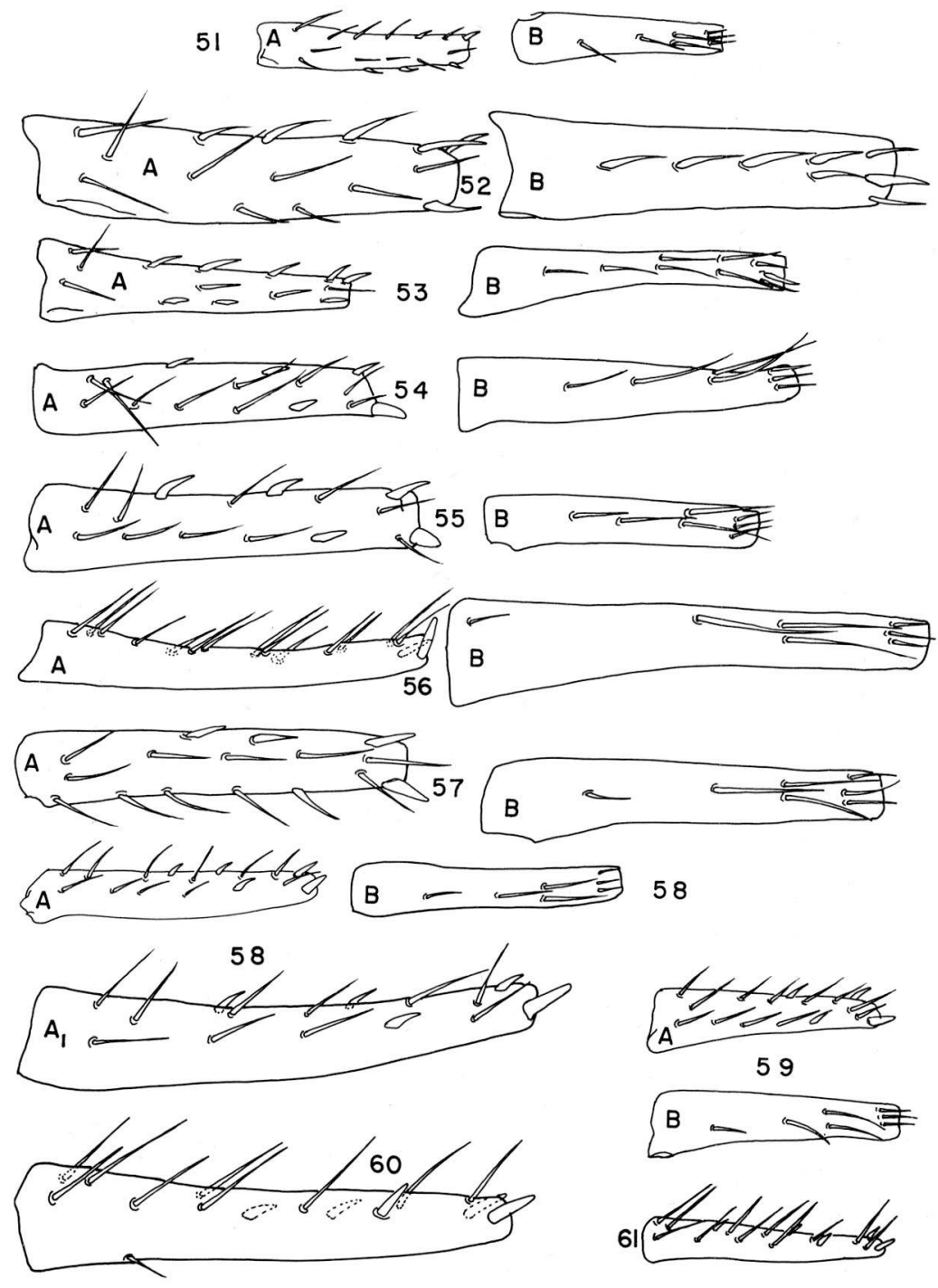




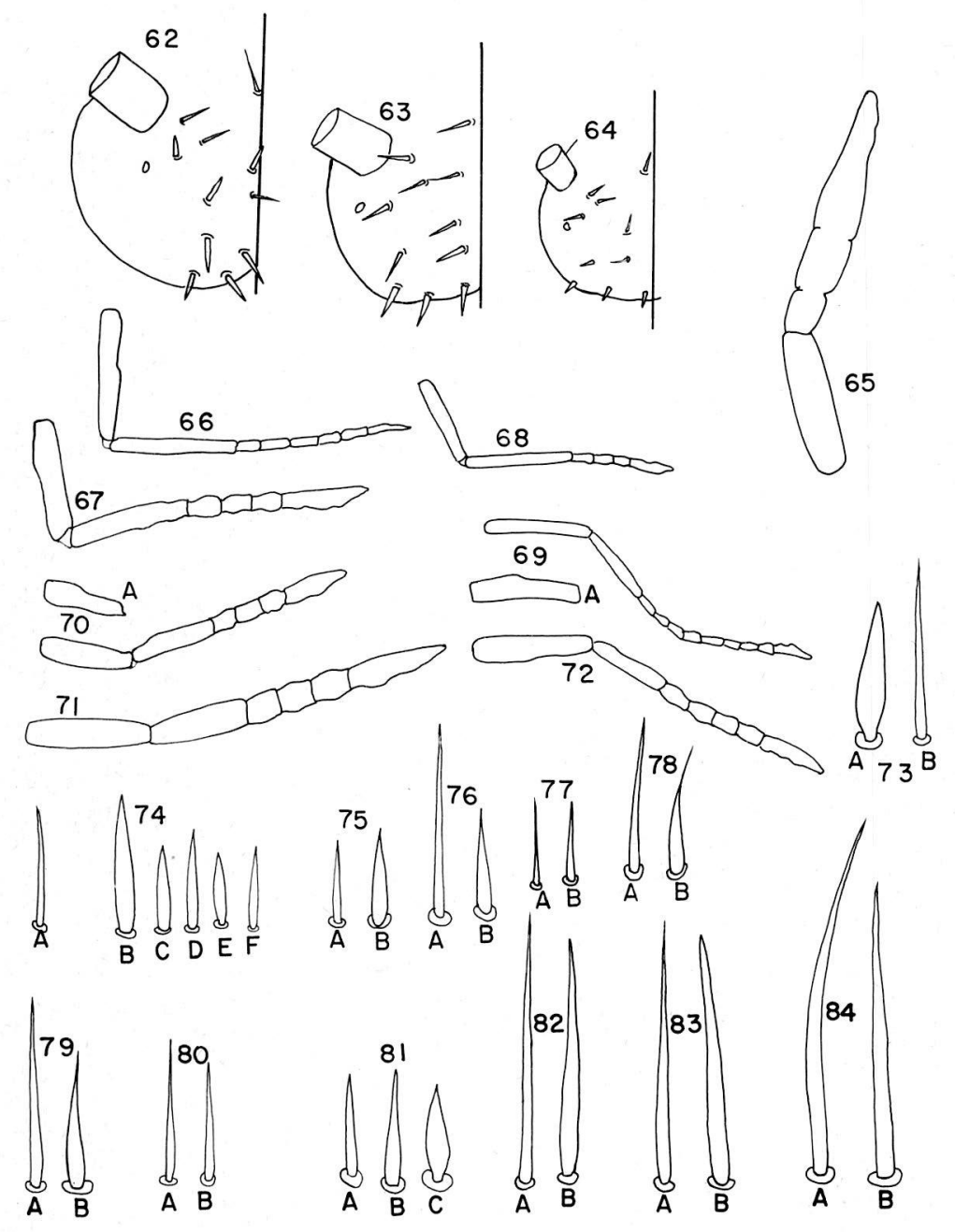



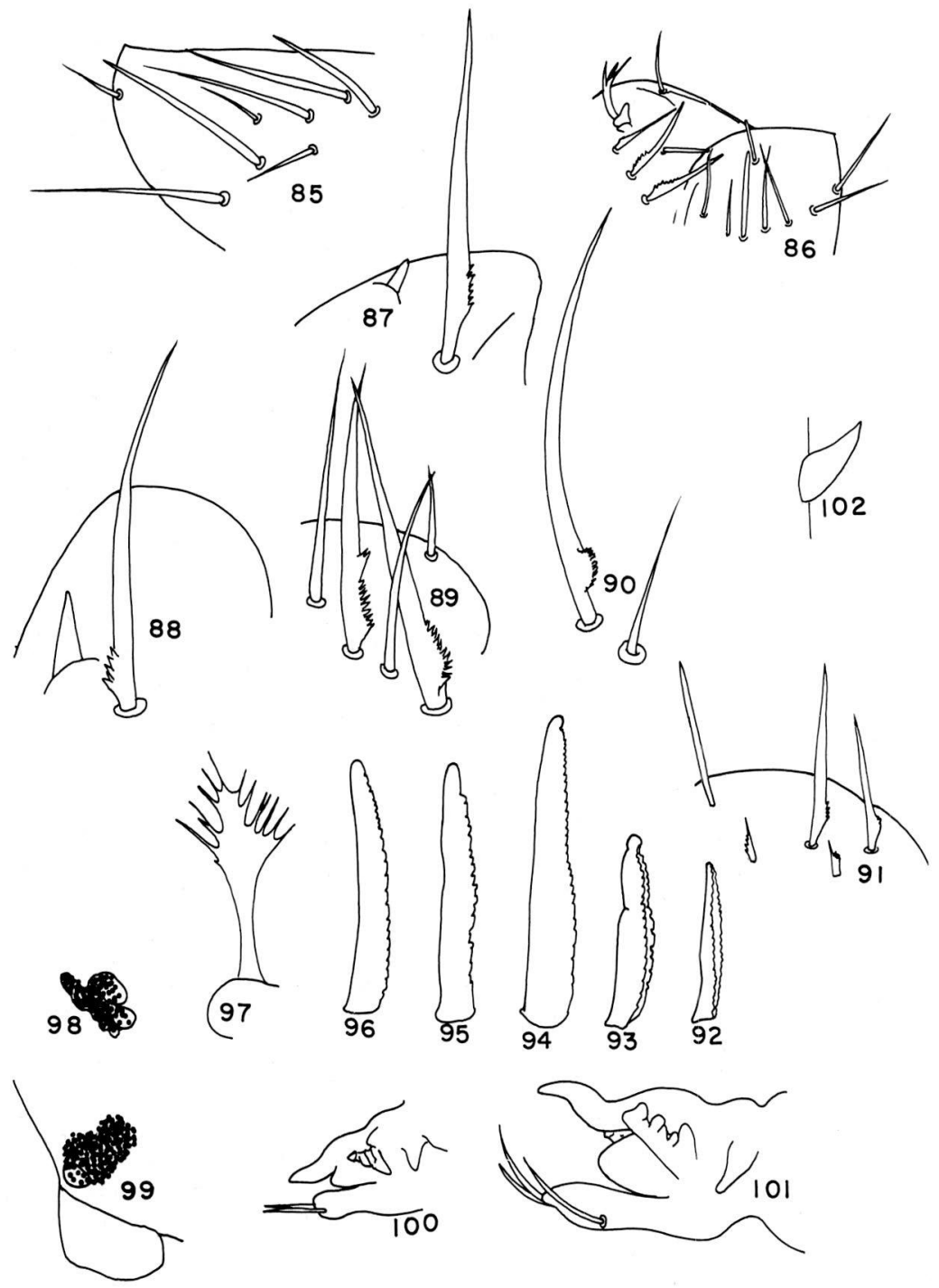
SPELEOLOGY II

(Christiansen, 7)

PLATE 17

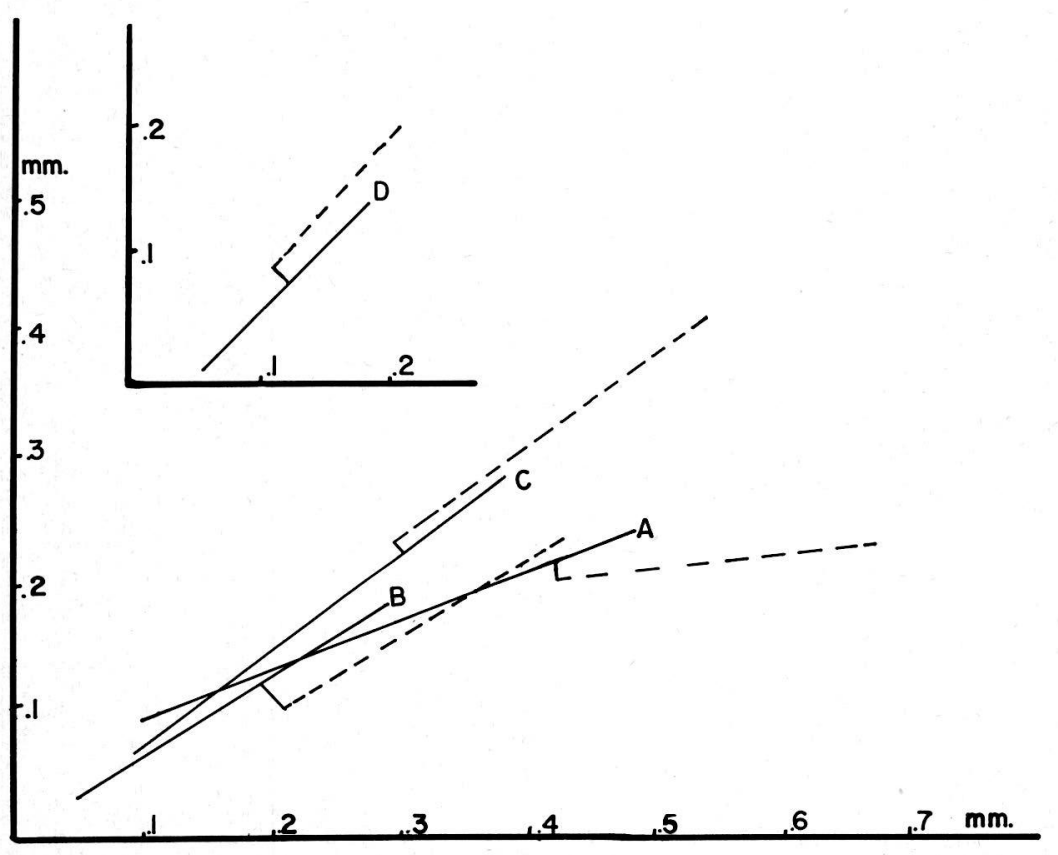



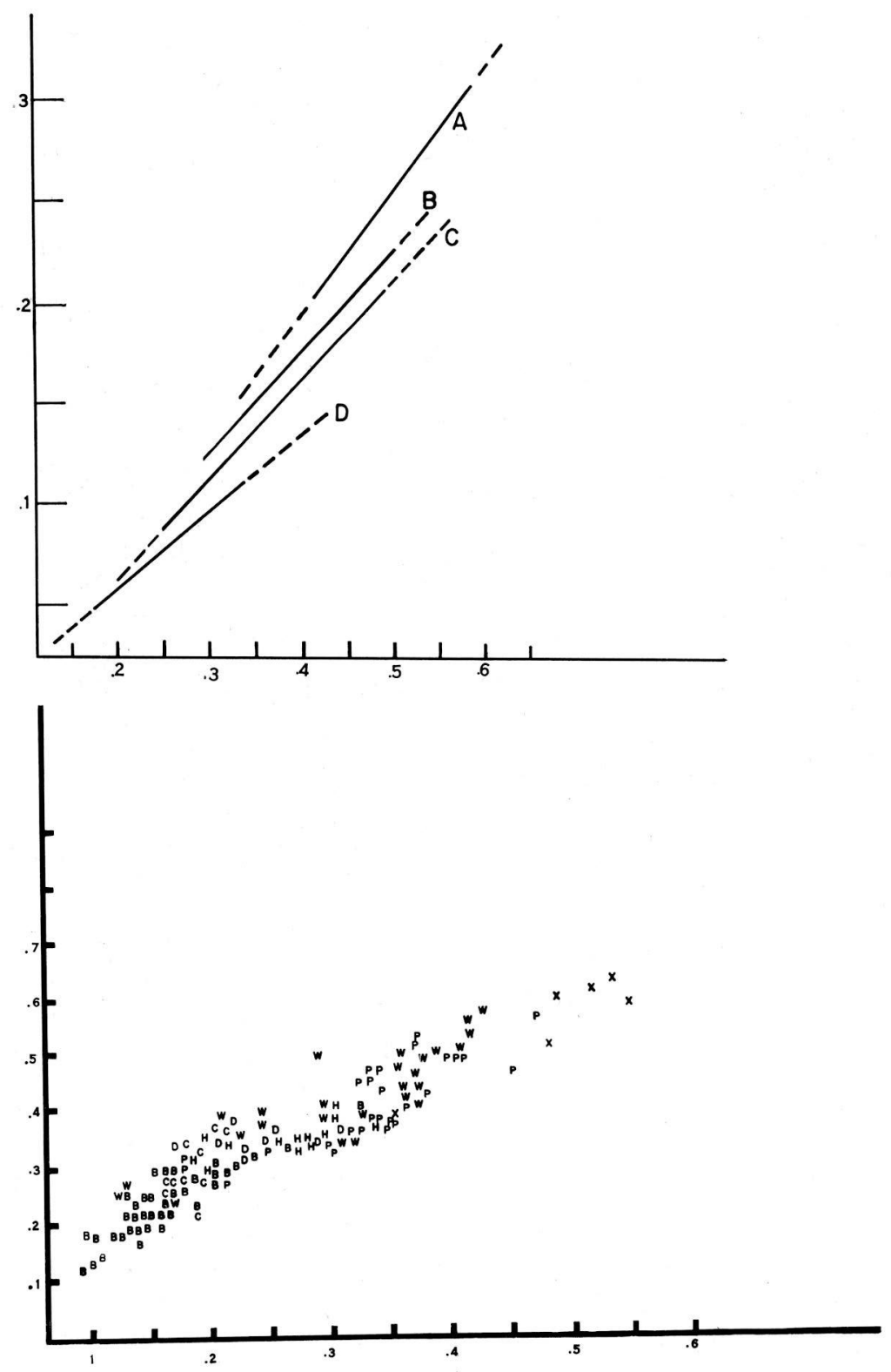


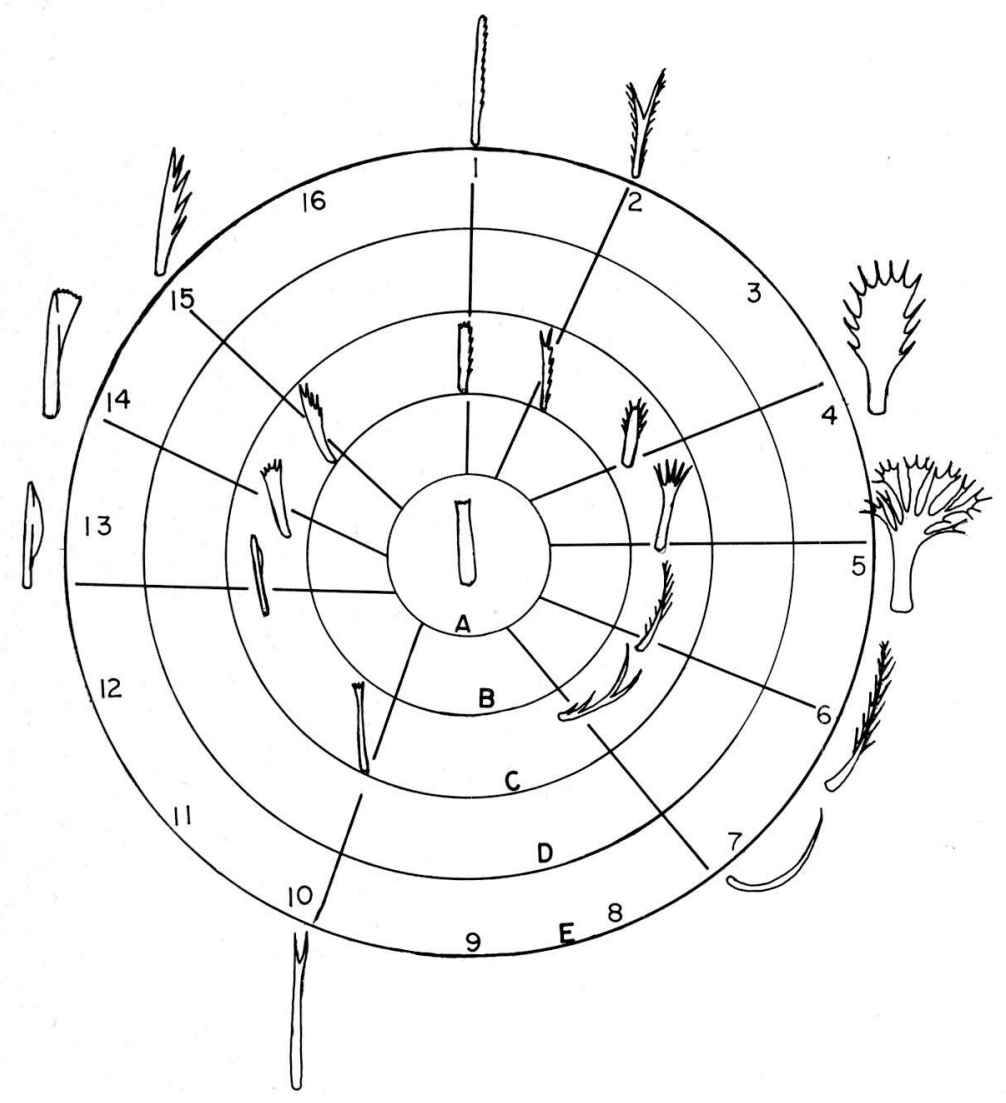

